\title{
Larval Zebrafish Lateral Line as a Model for Acoustic Trauma
}

Phillip M. Uribe, ${ }^{1}$ Beija K. Villapando, ${ }^{2}$ Kristy J. Lawton, ${ }^{2}$ Zecong Fang, ${ }^{3}$ Dmitry Gritsenko, ${ }^{4}$ Ashwin Bhandiwad, ${ }^{5}$ Joseph A. Sisneros, ${ }^{5}$ Jie $\mathrm{Xu}_{,}{ }^{4}$ and ${ }^{\circ}$ Allison B. Coffin ${ }^{1,2}$

\section{DOI:http://dx.doi.org/10.1523/ENEURO.0206-18.2018}

\author{
${ }^{1}$ Department of Integrative Physiology and Neuroscience, Washington State University, Vancouver, WA 98686 \\ ${ }^{2}$ College of Arts and Sciences, Washington State University, Vancouver, WA 98686, ${ }^{3}$ Mechanical Engineering \\ Department, Washington State University, Vancouver, WA 98686, ${ }^{4}$ Department of Mechanical and Industrial \\ Engineering, University of Illinois at Chicago, Chicago, IL 60607, and ${ }^{5}$ Department of Psychology, University of \\ Washington, Seattle, WA 98195
}

\section{Visual Abstract}

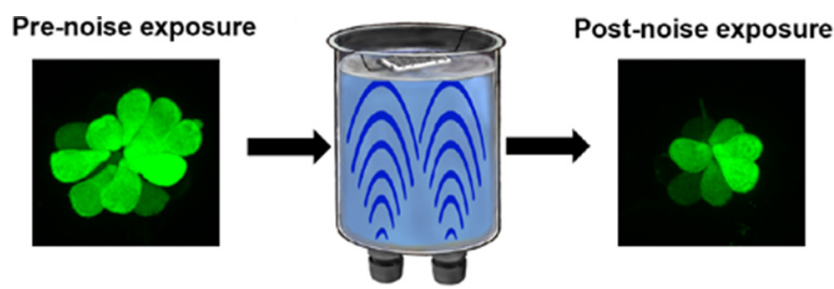

Excessive noise exposure damages sensory hair cells, leading to permanent hearing loss. Zebrafish are a highly tractable model that have advanced our understanding of drug-induced hair cell death, yet no comparable model exists for noise exposure research. We demonstrate the utility of zebrafish as model to increase understanding of hair cell damage from acoustic trauma and develop protective therapies. We created an acoustic trauma system using underwater cavitation to stimulate lateral line hair cells. We found that acoustic stimulation resulted in exposure time- and intensity-dependent lateral line and saccular hair cell damage that is maximal at $48-72 \mathrm{~h}$ post-trauma. The number of TUNEL + lateral line hair cells increased $72 \mathrm{~h}$ post-exposure, whereas no increase was observed in TUNEL+ supporting cells, demonstrating that acoustic stimulation causes hair cell-specific damage. Lateral line hair cells damaged by acoustic stimulation regenerate within $3 \mathrm{~d}$, consistent with prior regeneration studies utilizing ototoxic drugs. Acoustic stimulation-induced hair cell damage is attenuated by pharmacological inhibition of protein synthesis or caspase activation, suggesting a requirement for translation and activation of apoptotic signaling cascades. Surviving hair cells exposed to acoustic stimulation showed signs of synaptopathy, consistent with mammalian studies. Finally, we demonstrate the feasibility of this platform to identify compounds that prevent acoustic trauma by screening a small redox library for protective compounds.

\section{Significance Statement}

Noise overexposure damages hair cells, leading to permanent hearing loss. A critical step in understanding and preventing noise-induced hearing loss (NIHL) is establishing an accessible in vivo model to test for genetic and chemical modulators of noise damage. We developed a novel acoustic trauma system, using cavitation, to stimulate and damage zebrafish lateral line hair cells. We demonstrate that acoustic stimulation damages zebrafish lateral line hair cells in an exposure time- and intensity-dependent manner, consistent with acoustic trauma research in mammals. This novel system provides a model for in vivo, real-time studies of noise exposure, and for rapid discovery of chemical and genetic modulators of acoustic trauma-induced hair cell damage. 
Our data suggest that acoustic stimulation results in lateral line hair cell damage consistent with acoustic trauma research in mammals, providing a highly tractable model for high-throughput genetic and drug discovery studies.

Key words: acoustic trauma; hair cell; hearing loss; lateral line; zebrafish

\section{Introduction}

Noise-induced hearing loss (NIHL) is the most common cause of hearing loss and the second most common occupational illness in the United States (Bureau of Labor Statistics, 2006). The effects of NIHL are comorbid with depression, social isolation, and functional decline (Mick et al., 2014). Noise exposure can lead to permanent hearing impairment as the result of damage to mechanosensory hair cells within the cochlea. Despite identification of cell death cascades associated with acoustic trauma, there is a lack of information about damage onset and progression. Further, although many candidate protective targets have been identified in rodents, no FDA-approved therapy exists and target innovation has been slow (Le Prell et al., 2007). Thorough characterization of the progression of hair cell degeneration following noise exposure would represent a major advancement toward understanding and preventing NIHL. This goal necessitates the development of a more accessible platform where viable hair cells can be rapidly assessed in vivo.

Overexposure to intense noise causes hair cell damage 1-14 d after exposure and results in permanent threshold shifts (Wang et al., 2002). A primary biochemical mechanism of noise-induced hair cell damage is overproduction of reactive oxygen species (ROS; Henderson et al., 2006). Immediately following noise trauma, hair cells exhibit increased ROS production that persists up to $10 \mathrm{~d}$. Antioxidant therapies reduce NIHL in rodent models, which is consistent with a ROS-mediated hair cell death mechanism (Yamane et al., 1995; Ohlemiller, 2008). ROS overproduction can lead to apoptosis or regulated necrosis,

Received May 23, 2018; accepted August 8, 2018; First published August 16, 2018.

The authors declare no competing financial interests.

Author contributions: P.M.U., B.K.V., K.J.L., J.X., A.B.C., Z.F., and D.G. designed research; P.M.U., B.K.V., K.J.L., Z.F., D.G., A.B., J.A.S., J.K., and A.B.C. performed research; P.M.U., B.K.V., K.J.L., J.A.S., and A.B.C. analyzed data; P.M.U., K.J.L., J.A.S., J.X., and A.B.C. wrote the paper.

This work was supported by the National Institutes of Health Grant R21DC015636 and a grant from the American Hearing Research Foundation (to A.B.C.) and by funding from Washington State University.

P. M. Uribe's present address: Otonomy, Inc., San Diego, CA 92121.

A. Bhandiwad's present address: National Institute of Child Health and Human Development, National Institutes of Health, Bethesda, MD 20892.

Z. Fang's present address: Department of Biomedical Engineering, University of California, Davis, CA 95616

Acknowledgements: We thank Anna Roche for help with preliminary experiments, Christopher Riso, Alexander Young, and Maria Sokolova for fish husbandry support, Teresa Nicolson for mariner mutant fish and ribeye antibody, and Ryan Todd for technical assistance with the cavitation device. We also thank the reviewers for feedback that improved this manuscript.

Correspondence should be addressed to Allison B. Coffin, Department of Integrative Physiology and Neuroscience, Washington State University, Vancouver, WA 98686, E-mail: allison.coffin@wsu.edu.

DOI:http://dx.doi.org/10.1523/ENEURO.0206-18.2018

Copyright @ 2018 Uribe et al.

This is an open-access article distributed under the terms of the Creative Commons Attribution 4.0 International license, which permits unrestricted use, distribution and reproduction in any medium provided that the original work is properly attributed. and both processes have been observed in noiseexposed hair cells (Hu et al., 2002; Nicotera et al., 2003).

In contrast, acoustic trauma that only induces temporary threshold shifts does not result in direct hair cell loss. Exposure to moderately intense noise causes cochlear synaptopathy, often leading to accelerated age-related hearing loss (Kujawa and Liberman, 2009; Sergeyenko et al., 2013; Fernandez et al., 2015). In humans, synaptopathy likely contributes to tinnitus, hyperacusis, and difficulty processing speech in noise (Liberman and Kujawa, 2017). Neurotrophic therapies such as neurotrophin-3 and BDNF show promise in regenerating cochlear synapses after noise damage (Sly et al., 2016; Suzuki et al., 2016), but more studies are needed to understand mechanisms of synaptopathy and develop preventative therapies.

The zebrafish lateral line, which contains hair cells homologous to those of the mammalian inner ear, represents a tractable model for studies of hair cell function, damage, and protection (Harris et al., 2003; Owens et al., 2008; Nicolson, 2017). The lateral line is located on the body surface and encodes mechanosensory stimuli, providing the sense of "distant touch" (Dijkgraaf, 1963). Our understanding of chemical ototoxicity has greatly benefited from the utility of larval zebrafish as a model (Coffin et al., 2013; Esterberg et al., 2013, 2014). Larval zebrafish are an ideal model for hair cell damage studies due to large clutch sizes, optical transparency, and small body size, which allow for treatments to be performed in well plates (Mathias et al., 2012). These characteristics enable in vivo imaging of damage processes and allow for rigorous quantitative exploration of the noise damage parameter space using a large number of animals. Additionally, large scale drug screens are possible using the larval zebrafish lateral line. These studies have identified novel otoprotective drug candidates that can preserve hearing in rodent models of ototoxicity, demonstrating that compounds initially identified in zebrafish translate to mammalian systems (Owens et al., 2008; Uribe et al., 2015; Chowdhury et al., 2018).

Here, we introduce a novel process to study acoustic trauma in larval zebrafish. Other groups have used underwater speakers to damage inner ear hair cells of fish but there have been no reports of an acoustic stimulus to damage lateral line hair cells (Popper and Fay 1973; Schuck and Smith, 2009). Our process uses cavitation, which occurs when dissolved gases in a fluid interact with ultrasonic waves resulting in oscillation of microbubbles. Microbubbles reach a maximum size and implode, emitting broadband shockwaves (Leighton, 1994). We demonstrate that underwater acoustic stimulation likely produced by cavitation specifically damages lateral line hair cells in a time- and intensity-dependent manner and is prevented by antioxidant therapy, consistent with mammalian models of acoustic trauma. Zebrafish represent a novel platform for understanding the timing of 
events in noise-damaged hair cells and for future highthroughput drug discovery studies aimed at preventing noise-induced hair cell damage.

\section{Materials and Methods}

\section{Zebrafish}

All zebrafish experiments were approved by the Washington State University Institutional Animal Care and Use Committee. Larval fish were reared at $28^{\circ} \mathrm{C}$ in Petri dishes containing water from the Washington State University Vancouver fish facility (900-1000 $\mu \mathrm{S}$ and 7.0-7.2 $\mathrm{pH})$. Transgenic myo6b:GFP zebrafish were used for direct hair cell counts (Kruger et al., 2016). The ty220d mariner mutant line (RRID: ZFIN_ZDB-GENO-140707) was used for studies that tested the necessity of functional mechanotransduction on acoustic stimulation-induced hair cell damage (Nicolson et al., 1998). All other experiments were performed in wild-type $(* \mathrm{AB})$ zebrafish.

\section{Cavitation device}

Four 40-kHz ultrasonic transducers (Beijing Ultrasonics) were epoxy mounted to the bottom of a 11.5-I stainless steel canister with a height of $28 \mathrm{~cm}$ and outer diameter of $24 \mathrm{~cm}$ (McMaster-Carr \#4173T37). Input power to two of the transducers was provided by a $300-W$ ultrasonic generator (Beijing Ultrasonics) to produce the broadband noise stimulus (the other two transducers provided physical stability but were not activated). An inline rheostat (part \#RHS20KE; Ohmite) was used to achieve finer control of power output. Fish were housed in a modified 24-well plate containing a 1-cm-thick layer of encased glycerol on the bottom to dampen cavitation energy.

\section{Hydrophone and accelerometer recordings}

The noise stimulus was calibrated using a minihydrophone to measure sound pressure (model 8103, Bruel and Kjaer) and a custom-modified triaxial accelerometer to measure particle acceleration (PCB model VW356A12 with $x$-axis sensitivity $=10.42 \mathrm{mV} / \mathrm{ms}^{-2}, y$-axis sensitivity $=9.65$ $\mathrm{mV} / \mathrm{ms}^{-2}$, and $z$-axis sensitivity $=10.14 \mathrm{mV} / \mathrm{ms}^{-2}$ ). During calibration, the hydrophone was positioned $\sim 2.5 \mathrm{~cm}$ below the water surface at the position where the middle of the modified 24-well plate sits in the water column. The accelerometer was placed on the top surface of the well plate and held in position with clay. Calibration measurements were made at four voltage outputs $(0.5,0.7,1.0,1.7 \mathrm{~V})$ from the ultrasonic generator and measured in terms of sound pressure level $(\mathrm{dB}$ re: $1 \mu \mathrm{Pa})$ and acceleration $(\mathrm{dB}$ re: $1 \mathrm{~ms}^{-2}$ ). The tri-axial accelerometer measurements in the $x-, y$-, and $z$-axes were reported as a combined magnitude vector and calculated as $20 \log \left(\sqrt{ }\left(x^{2}+y^{2}+z^{2}\right)\right)$ similar to Wysocki et al. (2009) and Vasconcelos et al. (2011).

\section{Acoustic trauma}

At $5 \mathrm{~d}$ post-fertilization (dpf), fish in a Petri dish were fed with a light dusting of GEMMA micro 75 (Skretting). All noise exposure experiments were conducted at $6 \mathrm{dpf}$ due to the small size and stereotyped neuromast location in this age of fish, which allows for high throughput hair cell assessment. Larval zebrafish were placed into wells
A2-A5 and D2-D5 of a modified 24-well plate (three fish per well) containing fish water and suspended atop $22 \mathrm{~cm}$ of water with the bottom $1 \mathrm{~cm}$ of the plate submerged (Fig. 1). Fish were exposed to an acoustic stimulus for periods ranging from 20 to $120 \mathrm{~min}$. Immediately following acoustic trauma, fish were transferred to a six-well plate (six fish per well) and raised on a 14/10 h light/dark cycle for up to $5 \mathrm{~d}$ post-exposure. Following exposure, fish were fed and $50 \%$ water changes were conducted daily for the duration of the experiment. Each post-exposure day evening (5-6 P.M.) fish were transferred to a clean six-well plate with fresh fish water.

\section{Hair cell assessment}

Survival of lateral line hair cells was assessed by vital dye labeling in live fish and direct hair cell counts in either live or fixed animals. The vital dye 2-(4-(dimethylamino)styryl)- $N$ ethylpyridinium iodide (DASPEl; Life Technologies) is a marker of mitochondrial membrane potential and stains lateral line hair cells (Harris et al., 2003). Fish were incubated in $0.005 \%$ DASPEI for $15 \mathrm{~min}$, rinsed twice with fish water, and anesthetized with $0.001 \%$ MS-222 (Argent Labs). Using a Leica M165FC fluorescence dissection scope, 10 anterior neuromasts (IO1, IO2, IO3, IO4, M2, Ml1, Ml2, O2, SO1, and SO2; Raible and Kruse, 2000) per fish were assessed based on fluorescence intensity (Harris et al., 2003; Coffin et al., 2009). An intensity score of 2 signifies bright neuromast fluorescence, an intermediate score of 1 represents dim DASPEI labeling, while a 0 neuromast score equates to no neuromast fluorescence at a given neuromast's stereotyped position. The scores from 10 neuromasts per fish were summed such that each fish receives a score between 0 (no neuromast fluorescence) and 20 (full complement of hair cells in all 10 neuromasts). DASPEl scoring is tightly correlated with direct hair cell counts (Harris et al., 2003; Coffin et al., 2013). DASPEI scores were only recorded once per fish and fish were euthanized immediately following neuromast assessment.

Direct hair cell counts were obtained from live myo6b: EGFP transgenic larvae (which express hair cell-specific cytoplasmic EGFP) or fixed $* \mathrm{AB}$ or mariner mutant fish immunohistochemically labeled with anti-parvalbumin to visualize hair cells. To perform direct hair cell counts in non-transgenic animals, fish were euthanized with an overdose of buffered MS-222 and fixed with 4\% paraformaldehyde (PFA) overnight at $4^{\circ} \mathrm{C}$. Fish were then rinsed twice with PBS for 10 min each and then once with $\mathrm{dH}_{2} \mathrm{O}$ for $20 \mathrm{~min}$. Larvae were then transferred to blocking solution consisting of $5 \%$ goat serum in PBST $(0.1 \%$ Triton $\mathrm{X}-100$; Sigma-Aldrich) for $1 \mathrm{~h}$. After blocking, fish were incubated in mouse anti-parvalbumin (1:500; EMD Millipore) diluted in $0.1 \%$ PBST with $1 \%$ goat serum overnight at $4^{\circ} \mathrm{C}$ (Coffin et al., 2013). Fish were then rinsed three times in $0.1 \%$ PBST and incubated for $4 \mathrm{~h}$ in Alexa Fluor 488 secondary antibody (Life Technologies) diluted in $0.1 \%$ PBST at room temperature (RT). Unbound secondary antibody was rinsed off by three 10 -min $0.1 \%$ PBST rinses. Labeled fish were stored in 1:1 PBS: glycerol for up to one week before imaging. Hair cells from five neuro- 
A

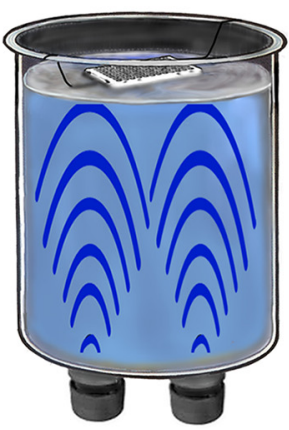

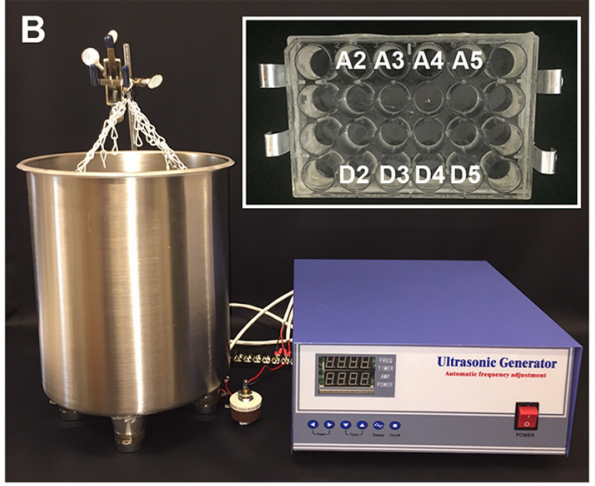

D

C
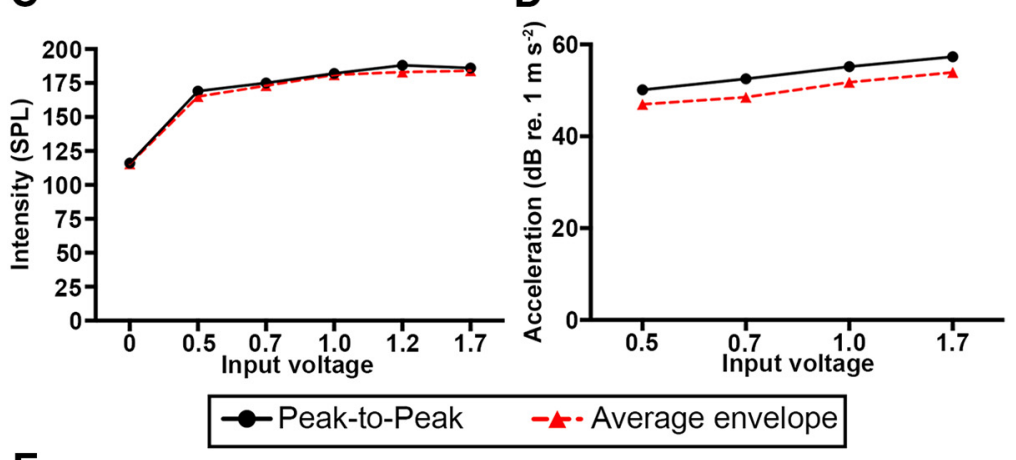

E

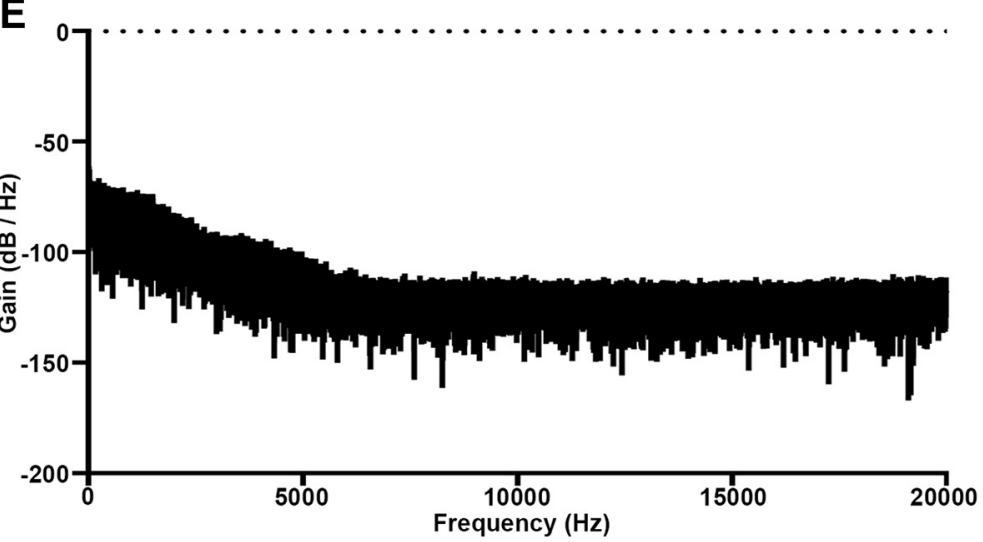

Figure 1. Cavitation device produces intense underwater sound pressure and well plate acceleration. $\boldsymbol{A}$, $\boldsymbol{B}$, Two ultrasonic transducers emit stimuli at $40 \mathrm{kHz}$ creating underwater cavitation within the attached stainless steel tank. The signal was generated with a 300-W ultrasonic generator with inline rheostat for fine amplitude adjustment. $\boldsymbol{B}$, inset, Larval zebrafish are exposed to acoustic stimulation, likely produced by cavitation, in labeled wells of a modified 24-well plate encased in glycerol resting atop $22 \mathrm{~cm}$ of water. $\boldsymbol{C}$, Sound pressure levels measured via hydrophone show increasing intensity with increasing input voltage. $\boldsymbol{D}$, Peak amplitude of well plate acceleration (measured from the top of the well plate) increases somewhat linearly with input voltage while average envelope exhibits a more modest increase. $\boldsymbol{E}$, Fast Fourier transform of power spectrum produced by cavitation device shows broadband energy within the low-frequency range.

masts (IO1, IO2, IO3, M2, OP1) per fish were counted using a Leica DMRB fluorescent microscope.

\section{Pharmacology}

All inhibitors were added to six-well plates immediately after exposed fish were removed from the device. Inhibitors were refreshed during the same intervals as fish water (twice daily) until the end of the desired exposure window. To test the role of protein synthesis we pulse treated fish immediately after acoustic trauma for $4 \mathrm{~h}$ with the protein synthesis inhibitor cycloheximide (C7698; Sigma Aldrich). In separate experiments we continuously treated acoustic trauma-exposed fish with either the pan caspase inhibitor Z-VAD-FMK (C7698; Sigma Aldrich) or the antioxidant D-methionine (F7111; UBPBio) to assess the contribution of caspase activation and ROS overproduction, respectively, in the acoustically stimulated lateral line. We also conducted a small blinded screen of select compounds from a larger redox library (BML-2835-0100; Enzo Life Sciences). Compounds chosen had either known protective effects in mammalian models of NIHL (as proof-ofconcept) or had not been previously tested against NIHL (to identify new protective molecules; Ohinata et al., 2000; 
Pourbakht and Yamasoba, 2003; Sergi et al., 2006; Bielefeld et al., 2007; Minami et al., 2007).

\section{FM 1-43 uptake}

We quantified FM 1-43 uptake following acoustic stimulation as a proxy for hair cell mechanosensory activity (Kindt et al., 2012). Briefly, we immersed larval zebrafish in $3 \mu \mathrm{M}$ FM 1-43FX (F35355; Thermo Fisher) for $30 \mathrm{~s}$ followed by four 30-s washes in fish water. Fish were then immediately anesthetized with $0.001 \%$ MS-222 and imaged using confocal microscopy with a $40 \times$ water immersion objective. Z-stack images of M2 neuromasts were collected and compressed using Leica LAS AF software (Raible and Kruse, 2000). Mean neuromast fluorescence and background fluorescence were measured using ImageJ v. 1.48 (National Institutes of Health). For each image, background fluorescence was subtracted from neuromast fluorescence to yield the reported neuromast fluorescence value (Kruger et al., 2016). Following live imaging of FM 1-43-labeled fish, larvae were fixed in 4\% PFA and labeled with anti-parvalbumin for hair cell quantification, as described above.

\section{Cell death assay}

We used a TUNEL assay to label dying cells. Acoustically stimulated fish were euthanized and fixed with $4 \%$ PFA ( $2 \mathrm{~h}$ at RT) at various post-exposure time points ( 0 , 24,48 , or $72 \mathrm{~h}$ ). Fish were then incubated in proteinase $\mathrm{K}$ $(20 \mu \mathrm{g} / \mathrm{ml})$ for $10 \mathrm{~min}$ followed by a $5 \mathrm{~min}$ PBS wash and $5 \mathrm{~min}$ in ice cold acetic acid:ethanol $(1: 2)$ at $-20^{\circ} \mathrm{C}$. After two 5-min PBS washes, fish were exposed to 75- $\mu$ l equilibrium buffer for $30 \mathrm{~s}$ followed by incubation in 55- $\mu$ l working strength TdT for $1 \mathrm{~h}$ at $37^{\circ} \mathrm{C}$ (EMD Millipore $\mathrm{S} 7165)$. After $1 \mathrm{~h}, 1 \mathrm{ml}$ of stop wash buffer was added followed by three $1 \mathrm{~min}$ PBS washes and $30 \mathrm{~min}$ in nnti-dig/block solution. Fish were then rinsed four more times with PBS and immunohistochemically processed with anti-parvalbumin as described above. Three neuromasts $(\mathrm{IO} 1, \mathrm{IO} 2$, and IO3) per fish were imaged on a Leica SP8 confocal microscope. We quantified the number of TUNEL+/parv + cells per neuromast to determine the number of dying hair cells. We also quantified the number of TUNEL+/parv- cells within a $50 \times 50 \mu \mathrm{m}$ field of view surrounding the hair cells as a measure of cell death in non-sensory cells.

\section{Synaptic protein labeling}

We labeled pre- and postsynaptic proteins in acoustically exposed fish to assess synaptopathy following noise exposure. To label hair cell nuclei, live fish were treated with DAPI (1:1000 in system fish water) for $30 \mathrm{~min}$. Following DAPI treatment, fish were immediately fixed in $4 \%$ PFA supplemented with $4 \%$ sucrose and $0.2 \mathrm{mM} \mathrm{CaCl}_{2}$ at $4^{\circ} \mathrm{C}$ for $4 \mathrm{~h}$. Fish were then rinsed three times in PBS for

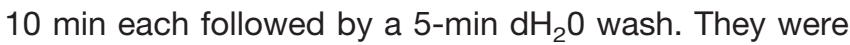
then permeabilized with ice cold acetone for $10 \mathrm{~min}$ followed by a $5-\mathrm{min}_{\mathrm{dH}} \mathrm{O}$ rinse. Fish were then transferred to blocking solution $(0.1 \%$ Tween PBST, $1 \%$ DMSO, $1 \%$ BSA and, $2 \%$ goat serum) for $1 \mathrm{~h}$ at RT. After blocking, fish were incubated with primary antibodies against the postsynaptic density protein MAGUK (NeuroMab clone
$\mathrm{K} 28 / 86 ; 1: 500$ ) and the presynaptic ribbon synapse protein ribeye $b$ (gift of $\mathrm{T}$. Nicolson; 1:500) overnight at $4^{\circ} \mathrm{C}$. Excess primary antibody was rinsed off with four $30-\mathrm{min}$ PBS rinses. Finally, fish were incubated in Alexa Fluor antibodies $(1: 500)$ overnight at $4^{\circ} \mathrm{C}$. Fish were imaged on a Leica SP8 confocal microscope. To count ribbons, we quantified the total number of ribeye $b+$ punctae. As a measure of "orphaned" ribbons not associated with a functional synapse, we also quantified the number of ribeye $b+$ punctae that were not apposed with the postsynaptic marker MAGUK (Sheets et al., 2011).

\section{Experimental design and statistical analysis}

All experiments used animals $6-11 \mathrm{dpf}$ of either sex (sex cannot be determined at this age). Experiments used 8-16 fish per treatment group; animal numbers for each experiment are indicated in the figure legend associated with that experiment. Some experiments were performed blind to control for experimenter bias. Data were analyzed using GraphPad Prism (V. 6.0). Statistical analyses were performed using either an un-paired $t$ test assuming equal variance, one-, or two-way ANOVA, as appropriate, and are indicated on each figure legend. Post hoc comparisons were performed using Bonferroni corrections. Additional detail is provided in figure legends.

\section{Results}

\section{Acoustic output of the cavitation device}

To stimulate the lateral line of larval zebrafish we developed a novel cavitation device with finely incremented power control. We attached four $40-\mathrm{kHz}$ ultrasonic transducers to the bottom of a water-filled stainless steel tank (Fig. $1 A, B$ ). The transducers were powered by a $300-\mathrm{W}$ ultrasonic generator with inline rheostat that allowed for fine control of power output. During cavitation, zebrafish were housed in a custom 24-well plate encased in glycerol (Fig. 1B, inset). Using a hydrophone, we measured sound pressure just beneath the surface of the water bath. We found that both peak amplitude and average sound pressure envelope increased with input voltage up to saturation at 169- and 165-dB SPL (re: $1 \mu \mathrm{Pa}$ ), respectively, with a driving power of $1.2 \mathrm{~V}$ (Fig. 1C). Peak amplitude of acceleration, measured on top of the well plate, increased in a steep linear fashion with voltage input while the increase in average envelope was more modest (Fig. $1 D$ ). Fast Fourier transform of the power spectrum shows that the stimulus is broadband, with the bulk of the energy concentrated in the low frequency range (Fig. 1E). These results demonstrate that our cavitation device produces intense broadband underwater sound pressure and well plate acceleration that can be controlled by adjusting input voltage.

\section{Acoustic stimulation damages lateral line hair cells}

To assess the effects of acoustic stimulation on lateral line hair cell survival, we exposed zebrafish to acoustic stimulation and assessed hair cell survival via DASPEI staining. Unexposed controls labeled with the vital dye DASPEI display bright neuromast fluorescence indicative of intact hair cells (Fig. 2A). Fish exposed to acoustic 

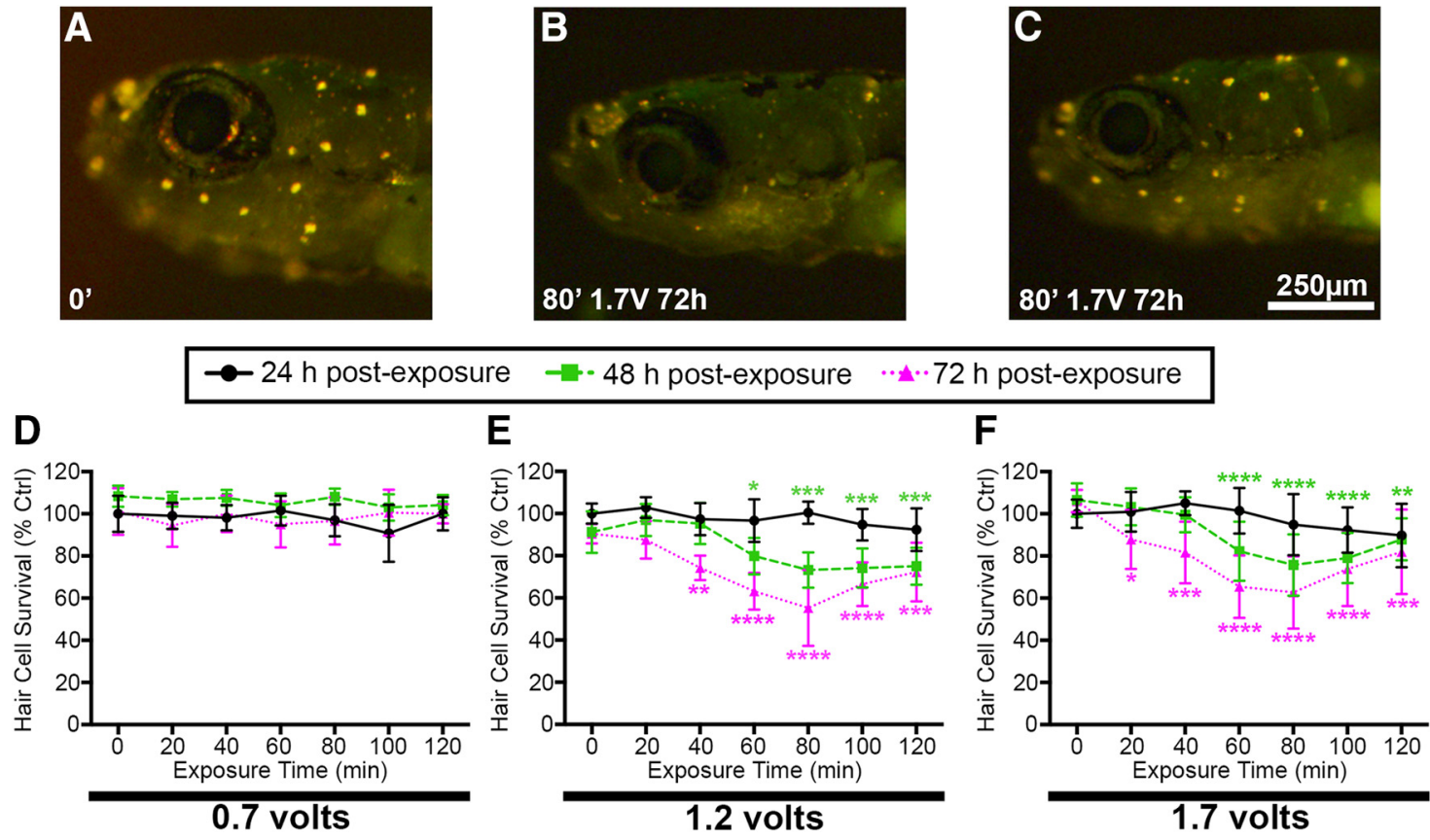

Figure 2. Acoustic stimulation results in exposure time-, intensity-, and post-exposure time-dependent reduction in DASPEI labeling, indicative of hair cell damage. $\boldsymbol{A}-\boldsymbol{C}$, Representative images of $(\boldsymbol{A})$ unexposed larval zebrafish and $(\boldsymbol{B}, \boldsymbol{C})$ fish exposed to acoustic stimulation. Scale bar applies to all three images. Unexposed fish exhibit bright DASPEl staining indicative of a full complement of lateral line hair cells while fish exposed to 80 min of acoustic stimulation have diminished DASPEl labeling $72 \mathrm{~h}$ post-exposure. Two representative images of acoustically exposed fish are shown to depict the diversity of DASPEI labeling observed. $\boldsymbol{D}-\boldsymbol{F}, \mathbf{Q u a n t i f i c a t i o n}$ of acoustic stimulation-induced hair cell loss. $\boldsymbol{D}$, Fish exposed to $0.7 \mathrm{~V}$ show no reduction in DASPEl labeling. $\boldsymbol{E}$, Fish exposed to 1.2 $V$ of acoustic stimulation exhibit the greatest reduction in DASPEl labeling after 80 min of exposure and $72 \mathrm{~h}$ post-exposure. $\boldsymbol{F}, 1.7$ $\mathrm{V}$ of acoustic stimulation produces similar DASPEI reduction to $1.2 \mathrm{~V}$. Asterisks indicate significant differences from age-matched unexposed controls $(* p<0.05, * * p<0.01$, $* * * p<0.005, * * * * p<0.001$ ). Statistical analysis is shown in Table $1 . N=10-12$ animals per treatment, values are mean \pm SD.

stimulation at $1.7 \mathrm{~V}$ for 80 min exhibit dimmer DASPEI fluorescence than unexposed controls, indicating that acoustic stimulation reduces hair cell number (Fig. 2B,C). Acoustically-exposed fish demonstrate variability in hair cell damage, as shown in Figure 2. For example, fish in Figure 2B,C were exposed to the same damage paradigm but exhibit different degrees of hair cell survival. Fish housed in the device for $8 \mathrm{~h}$ with no voltage input had DASPEl labeling consistent with unexposed controls at all post-exposure time points, indicating that handling and housing in the device does not contribute to the decreased DASPEI labeling seen in the acoustically-exposed larvae (data not shown). For the lowest voltage tested $(0.7 \mathrm{~V})$, acoustical stimulation up to $120 \mathrm{~min}$ resulted in no reduction of hair cell survival for any time points tested (Fig. 2D; Table 1). By contrast, $80 \mathrm{~min}$ of $1.2-\mathrm{V}$ acoustic stimulation produced a $24 \%$ and $39 \%$ decrease in hair cell survival for post-exposure times of 48 and $72 \mathrm{~h}$, respectively (Fig. $2 E$ ). Hair cell survival was lowest for $80 \mathrm{~min}$ of exposure and $72 \mathrm{~h}$ of post-exposure recovery time. Moreover, the acoustic stimulation induced at $1.7 \mathrm{~V}$ produced a similar degree of hair cell damage as that at $1.2 \mathrm{~V}$ (Fig. 2F). For both 1.2- and 1.7-V driving voltages there was a gradual decline in hair cell survival with increasing exposure time up to $80 \mathrm{~min}$. Interestingly, hair cell survival scores were consistently higher at $100-$ and 120-min exposure times. This increased hair cell survival may be a result of earlier onset of hair cell death and subsequent regeneration.

To validate DASPEI scores, we exposed transgenic myo6b:GFP fish to acoustic stimulation and obtained direct hair cell counts of GFP-positive cells. Acoustic stimulation caused a significant loss of lateral line hair cells, consistent with the reduction in DASPEl fluorescence (Fig. 3). The acoustic stimulation induced at $1.2 \mathrm{~V}$ reduced anterior lateral line hair cell survival at both $80-$ and 120 min exposure times after either 48 or $72 \mathrm{~h}$ post-exposure (Fig. 3C). For acoustic stimulation induced at $1.2 \mathrm{~V}$ for 80 min, hair cell number was reduced by $50 \%$ and $28 \%$ for post-exposure times of 48 and $72 \mathrm{~h}$ respectively. Exposure to $1.7-\mathrm{V}$ acoustic stimulation similarly reduced anterior lateral line hair cell survival (Fig. 3D). Acoustic stimulation at $1.7 \mathrm{~V}$ for 80 min reduced hair cell number by $42 \%$ and $31 \%$ for post-exposure times of 48 and $72 \mathrm{~h}$, respectively. We then examined the effect of acoustic stimulation on two posterior lateral line (pLL) neuromasts ( $\mathrm{p} 1$ and p2) to determine whether the acoustic trauma effect is consistent across the lateral line system. Both 1.2- and 1.7-V driving voltages caused significant damage in the pLL at $72 \mathrm{~h}$ post-exposure (Fig. 3E,F). Collectively, DASPEI and direct hair cell counts indicate that 1.2- or 1.7-V acoustic stimulation results in robust hair cell damage when assessed 48 or $72 \mathrm{~h}$ post-exposure. 
Table 1. Statistical analysis of hair cell survival, as determined by DASPEI assessment (Fig. 2) or hair cell counts (Fig. 3)

\begin{tabular}{|c|c|c|c|c|}
\hline Assessment method & Voltage & Variable & F score & $p$ value \\
\hline \multirow[t]{3}{*}{ DASPEI } & $0.7 \mathrm{~V}$ & Exposure time & $F_{(12,211)}=1.54$ & $p=0.2396$ \\
\hline & & Recovery time & $F_{(6,211)}=1.34$ & $p<0.0001$ \\
\hline & & Interaction & $F_{(12,211)}^{(1,211)}=1.54$ & $p=0.1131$ \\
\hline \multirow[t]{3}{*}{ DASPEI } & $1.2 \mathrm{~V}$ & Exposure time & $F_{(6,216)}=25.26$ & $p<0.0001$ \\
\hline & & Recovery time & $F_{(2,216)}=144.0$ & $p<0.0001$ \\
\hline & & Interaction & $F_{(12,216)}=6.23$ & $p<0.0001$ \\
\hline \multirow[t]{3}{*}{ DASPEI } & $1.7 \mathrm{~V}$ & Exposure time & $F_{(6,216)}=19.72$ & $p<0.0001$ \\
\hline & & Recovery time & $F_{(2,216)}=38.83$ & $p<0.0001$ \\
\hline & & Interaction & $F_{(12,216)}=4.33$ & $p<0.0001$ \\
\hline \multirow[t]{3}{*}{ Hair cell counts } & $1.2 \mathrm{~V}$ aLL & Exposure time & $F_{(2,91)}=13.39$ & $p<0.0001$ \\
\hline & & Recovery time & $F_{(2,91)}=12 \cdot 30$ & $p<0.0001$ \\
\hline & & Interaction & $F_{(4,91)}=4.42$ & $p=0.0026$ \\
\hline \multirow[t]{3}{*}{ Hair cell counts } & $1.7 \mathrm{~V}$ aLL & Exposure time & $F_{(2,93)}=10.87$ & $p<0.0001$ \\
\hline & & Recovery time & $F_{(2,93)}=4.97$ & $p=0.0089$ \\
\hline & & Interaction & $F_{(4,93)}^{(2,00)}=3.02$ & $p=0.0217$ \\
\hline \multirow[t]{3}{*}{ Hair cell counts } & $1.2 \mathrm{~V} \mathrm{pLL}$ & Exposure time & $F_{(2,89)}=4.90$ & $p=0.0095$ \\
\hline & & Recovery time & $F_{(2,89)}=12.30$ & $p<0.0001$ \\
\hline & & Interaction & $F_{(4,89)}=3.27$ & $p=0.0151$ \\
\hline \multirow[t]{3}{*}{ Hair cell counts } & $1.7 \mathrm{~V} \mathrm{pLL}$ & Exposure time & $F_{(2,91)}^{(1,09)}=9.85$ & $p=0.0001$ \\
\hline & & Recovery time & $F_{(2,91)}^{(2,91)}=3.62$ & $p=0.0308$ \\
\hline & & Interaction & $F_{(4,91)}=6.50$ & $p=0.0001$ \\
\hline
\end{tabular}

All data were analyzed by two-way ANOVA.

\section{Acoustic stimulation damages saccular hair cells}

Adult zebrafish exposed to acoustic trauma exhibit hair cell damage within the saccule, the primary auditory end organ in most fishes (Popper and Fay 1973; Schuck and Smith, 2009). However, Weberian ossicles, which couple the swim bladder to the ear and significantly broaden the detectable frequency range, do not mature until $\sim 50 \mathrm{dpf}$, well past the age of the fish used in the present study (Grande and Young, 2004). To determine whether acoustic stimulation damages hair cells in the saccule of larval fish, we exposed myo6b:GFP fish to 1.7-V acoustic stimulation and assessed saccular hair cell number $72 \mathrm{~h}$ after exposure. Acoustic stimulation at $1.7 \mathrm{~V}$ for $120 \mathrm{~min}$ significantly reduced saccular hair cell density by $14 \%$ (Fig. 4). This result demonstrates that acoustic stimulation damages saccular hair cells in the larval zebrafish even in the absence of Weberian ossicles.

\section{Acoustic stimulation does not alter FM 1-43 loading}

In birds and mammals, hair cell tip links break from prolonged (4-48 h) exposure to intense noise and rapidly regenerate within $48 \mathrm{~h}$ (Pickles et al., 1987; Husbands et al., 1999). To test if acoustic stimulation results in damage to the mechanotransduction machinery, we measured loading of the mechanotransduction-dependent dye FM 1-43 at different post-exposure time points. FM 1-43 loading in acoustically-exposed hair cells was not significantly different from unexposed age-matched controls (Fig. 5). Immunohistochemical labeling of the same fish with parvalbumin demonstrates that this acoustic stimulation intensity was sufficient to cause hair cell loss at $72 \mathrm{~h}$ post-exposure (Fig. 5E). Hair cell labeling differences may contribute to the delayed onset of hair cell loss when compared to myo6b:GFP (Fig. 3). This result suggests that acoustic stimulation does not damage the mechanotransduction machinery, including tip links, for exposure times up to $80 \mathrm{~min}$.

\section{Acoustic stimulation decreases hair cell synapse number}

Cochlear hair cells exposed to moderate noise trauma exhibit a reduction in synaptic ribbons and an increase in orphaned ribbons that are unpaired with a post synaptic density (Kujawa and Liberman, 2009; Sergeyenko et al., 2013). To test if acoustic stimulation leads to synaptopathy in the lateral line we labeled fish with DAPI, presynaptic (ribeye b), and postsynaptic (MAGUK) markers. Colocalization of ribeye $b$ and MAGUK are indicative of synaptic contact. More orphaned ribeye b puncta (white arrows) are present in acoustically stimulated neuromasts than in unexposed controls (Fig. 6). In addition to reduced synaptic coupling, acoustic stimulation also caused a decrease in the number of presynaptic ribbons. Acoustic stimulation for 80 min decreased ribeye $b$ puncta per hair cell when compared to unexposed controls at $72 \mathrm{~h}$ postexposure (Fig. 6D). Thus, acoustic stimulation causes a synaptopathic-like phenotype in the larval zebrafish lateral line.

\section{Onset of acoustic stimulation-induced hair cell death}

We observed maximum hair cell damage at 48-h postacoustic stimulation (Figs. 2, 3). To determine the onset and specificity of acoustic trauma we examined TUNELand parvalbumin-labeled fish at four post-exposure time points. Unexposed neuromasts had few TUNEL + hair cells, whereas $1.7 \mathrm{~V}$ of acoustic stimulation for $80 \mathrm{~min}$ resulted in a 128\% increase in TUNEL + hair cells at $72 \mathrm{~h}$ post-exposure (Fig. 7). The chosen post-exposure time points may not fully capture all dying cells, which may explain the lack of TUNEL + hair cells at $48 \mathrm{~h}$ postexposure. The numbers of TUNEL + non-sensory cells are 

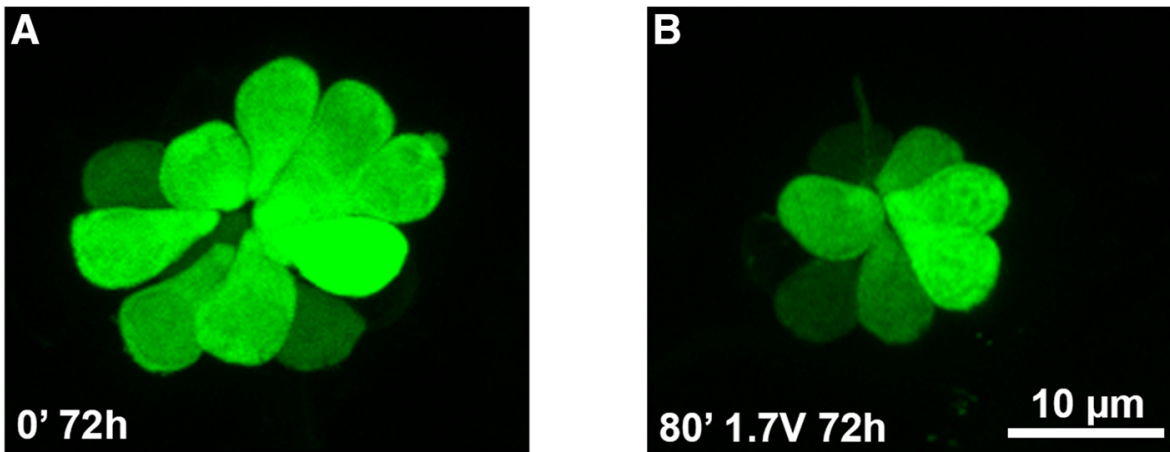

\section{$\rightarrow 24 \mathrm{~h}$ post-exposure $\rightarrow-48 \mathrm{~h}$ post-exposure $\cdot \cdot \cdot \cdot \cdot 72 \mathrm{~h}$ post-exposure}
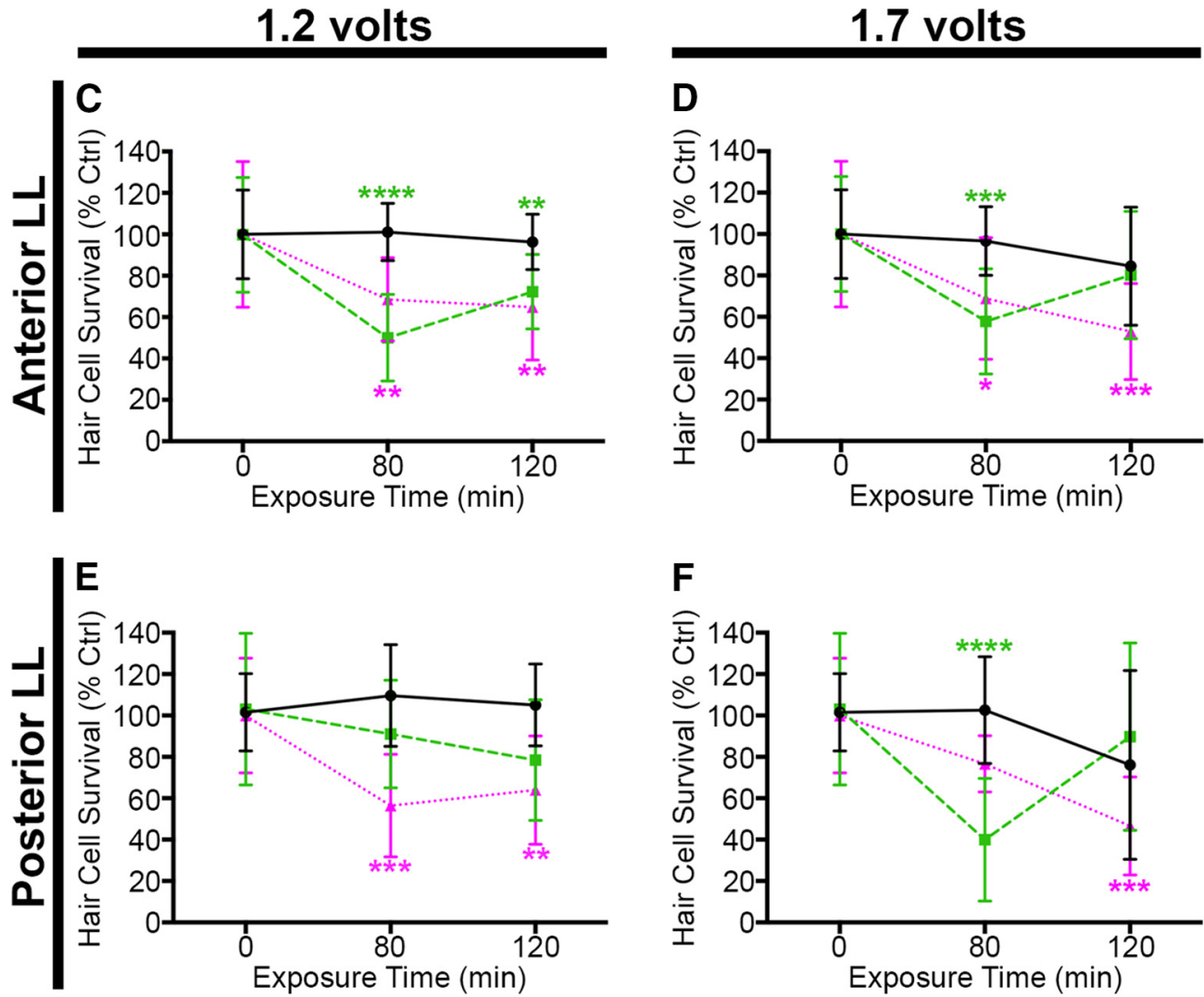

Figure 3. Acoustic stimulation decreases lateral line hair cell number. Unexposed $(\boldsymbol{A})$ and acoustically stimulated $(\boldsymbol{B}) \mathrm{O} 2$ neuromasts from myo6b:EGFP transgenic larval zebrafish. Scale bar applies to both images. $1.2 \vee(\boldsymbol{C})$ and $1.7 \vee(\boldsymbol{D})$ of acoustic stimulation significantly reduces the number of hair cells in five anterior lateral line neuromasts at 48 and $72 \mathrm{~h}$ after cessation of noise. $1.2 \mathrm{~V}(\boldsymbol{E})$ and $1.7 \mathrm{~V}(\boldsymbol{F})$ reduces hair cell number in pLL neuromasts P1 and P2. Asterisks indicate significant difference from age-matched unexposed controls $(* p<0.05, * * p<0.01, * * * p<0.005, * * * * p<0.0001$ ). Statistical analysis is shown in Table $1 . N=10-12$ animals per treatment, values are mean \pm SD.

similar between unexposed and exposed fish at all four post-exposure times points (Fig. 7D). These results demonstrate that hair cells are specifically damaged by acoustic stimulation whereas other non-sensory cell types exhibit similar TUNEL labeling to unexposed controls. Interestingly, TUNEL + non-sensory cells increase with post-exposure time in both exposed and unexposed fish, which may be due to cell death that has been observed during normal development (Williams and Holder, 2000).

\section{Hair cell regeneration after acoustic trauma}

Following damage with aminoglycosides, lateral line hair cells completely regenerate within $72 \mathrm{~h}$ (Ma et al., 2008). Hair cell regeneration was also observed in the adult zebrafish saccule following acoustic trauma (Schuck and Smith, 2009). We asked if larval lateral line hair cells regenerate following acoustic trauma by assessing hair cell survival with DASPEl every $24 \mathrm{~h}$ for up to $120-\mathrm{h}$ post-acoustic stimulation. Following maximum damage at 

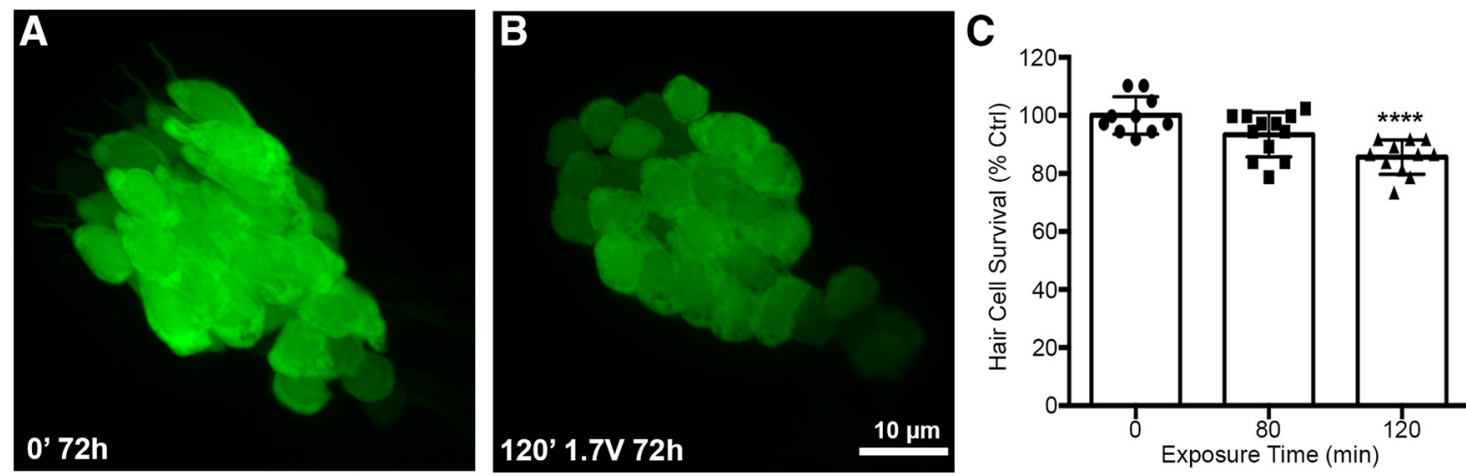

Figure 4. Acoustic stimulation produces an exposure time-dependent reduction in saccular hair cells. Unexposed (A) and acoustically stimulated $(\boldsymbol{B})$ saccules from myo6b:EGFP transgenic zebrafish. There was no obvious spatial pattern to the damage in the acoustically exposed saccules. C, Treatment with $1.7 \mathrm{~V}$ of acoustic stimulation for 120 min significantly reduces saccular hair cell number when assessed $72 \mathrm{~h}$ post-exposure (one-way ANOVA; exposure time: $F_{(2,30)}=11.89, p=0.0002$ ). Asterisks indicate significant difference from unexposed age-matched control $(* * * * p<0.001) . N=10-12$ animals per treatment, values represent mean $\pm \mathrm{SD}$.

$72 \mathrm{~h}$ post-exposure, hair cell survival scores returned to the level of unexposed controls $1 \mathrm{~d}$ later (Fig. 8). The extremely rapid regeneration may be accounted for by the staggered onset of hair cell loss, leading to staggered regeneration, unlike the synchronous damage that occurs from ototoxic drug exposure. This observation demonstrates that hair cells regenerate rapidly following acoustic trauma in a timeframe consistent with regeneration from drug insults.

\section{Mechanotransduction-deficient fish are resistant to acoustic trauma}

Mariner zebrafish have a defect in myosin VIla due to a point mutation encoding a premature stop codon, resulting in splayed hair bundles and greatly reduced mechanotransduction (Ernest et al., 2000). Mariner mutants exhibit reduced damage to aminoglycoside or cisplatin ototoxicity because these drugs rely on functional mechanotransduction for uptake (Wang and Steyger, 2009; Thomas et al., 2013). We exposed the F1 progeny from heterozygous mariner parents to acoustic stimulation to determine whether acoustic damage was reliant on a functioning mechanotransduction apparatus. Hair cell survival scores for exposed F1 progeny were distributed in two distinct groups that match the predicted Mendelian distribution (Fig. 9). Presumed carriers of the homozygous mutant allele exhibited resistance to acoustic damage while siblings carrying at least one copy of the wild-type allele had reduced hair cell survival scores. From this result we hypothesize that acoustic stimulation damage is reliant on a functional mechanotransduction apparatus.

\section{Caspase or protein synthesis inhibition prevents acoustic stimulation damage}

The relatively long-time course of acoustic stimulationinduced hair cell damage indicates that protein synthesis may be involved in damage. To test this hypothesis, we pulse treated fish with the protein synthesis inhibitor cycloheximide for $4 \mathrm{~h}$ immediately following acoustic trauma and assessed hair cell survival $72 \mathrm{~h}$ post-exposure. Cycloheximide treatment protected lateral line hair cells from acoustic trauma in a dose-dependent manner, demon- strating a reliance on protein synthesis for acoustic stimulation-induced hair cell damage (Fig. 10A). Acoustic trauma can also result in activation of cell stress pathways that result in caspase activation, leading to hair cell apoptosis (Kurabi et al., 2017). Cochlear hair cells exposed to noise trauma positively label for activated caspases 3,8 , and 9 (Hu et al., 2002; Nicotera et al., 2003). To test the reliance on caspase signaling in our acoustic damage model, we treated acoustic trauma-exposed fish with the caspase inhibitor Z-VAD for the entire $72 \mathrm{~h}$ post-exposure window. Z-VAD treatment at $1 \mu \mathrm{M}$ significantly reduced acoustic stimulation-induced hair cell damage (Fig. 10B). These results suggest that acoustic stimulation-induced hair cell damage requires activation of intracellular signaling mechanisms.

\section{Antioxidants prevent acoustic stimulation damage in the lateral line}

Overwhelming evidence demonstrates that oxidative stress occurs in hair cells exposed to acoustic trauma (Yamane et al., 1995; Henderson et al., 2006; Fetoni et al., 2013). Additionally, antioxidants are the most well studied compound class used to prevent NIHL (Ohlemiller, 2008). To assess if similar mechanisms are present in the acoustically stimulated lateral line, we treated acoustic stimulationexposed fish with the antioxidant D-methionine, which protects cochlear hair cells from acoustic injury (Cheng et al., 2008; Samson et al., 2008). D-methionine treatment protected lateral line hair cells from acoustic stimulation damage at both $100 \mu \mathrm{M}$ and $500 \mu \mathrm{M}$ concentrations (Fig. 11A). Finally, we used the zebrafish lateral line as a tool to screen a select redox library for compounds that prevent acoustic stimulation-induced damage. Four compounds (glutathione, baicalein, D- $\alpha$-tocopherylquinone, and ferulic acid ethylester) significantly protected lateral line hair cells from acoustic stimulation-induced hair cell damage (Fig. 11B), only one of which (glutathione) has been previously identified as a potential therapy to prevent NIHL (Ohinata et al., 2000). The pro-oxidant compound buthionine sulfoximine did not confer protection. This result demonstrates the utility of acoustic trauma in the zebrafish lateral line to identify novel compounds that prevent acoustic hair cell damage. 

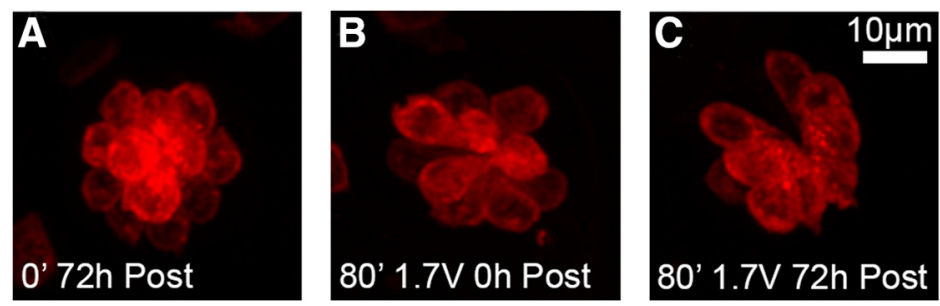

D

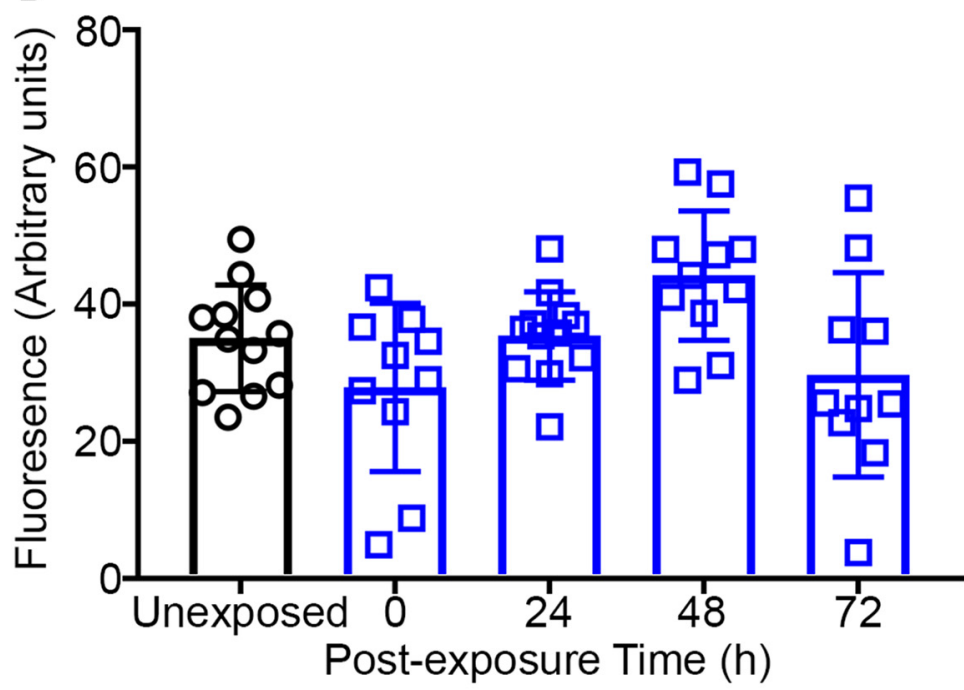

E

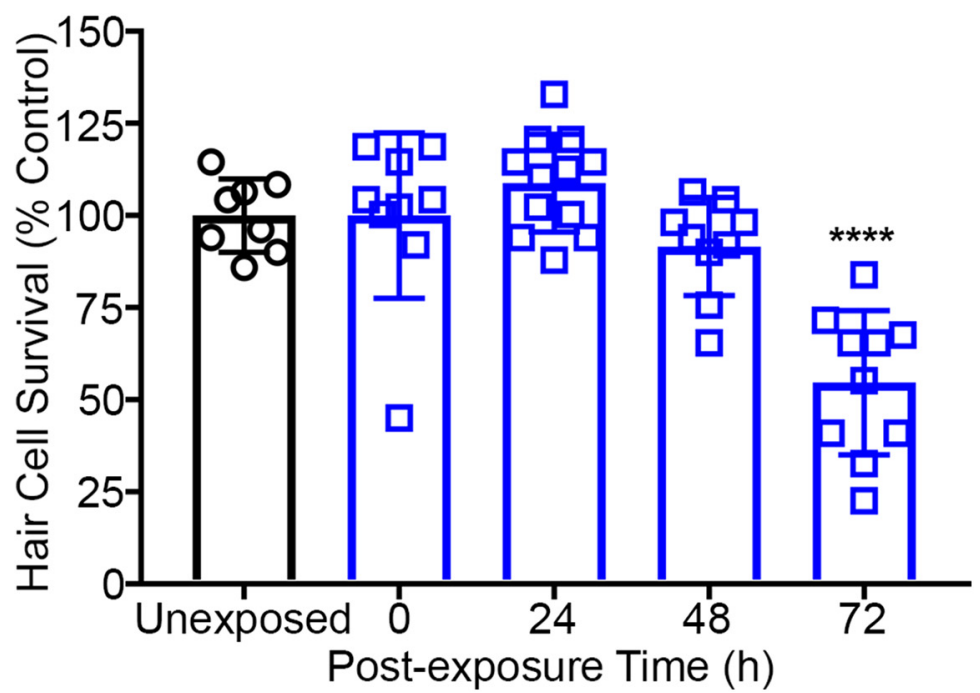

Figure 5. Loading of the mechanotransduction dependent dye FM 1-43FX is not affected by acoustic stimulation in wild-type $* A B$ zebrafish. $\boldsymbol{A}-\boldsymbol{C}$, Representative images of neuromasts loaded with FM 1-43FX. Unexposed $(\boldsymbol{A})$ and acoustically stimulated $(\boldsymbol{B}$, $\boldsymbol{C})$ neuromasts are brightly labeled with FM 1-43FX. $\boldsymbol{D}$, Quantified FM 1-43FX fluorescence (normalized to hair cell number) is not significantly different in unexposed control versus $72 \mathrm{~h}$ post-exposure suggesting that acoustic stimulation does not alter hair cell mechanotransduction (one-way ANOVA; post-exposure time: $F_{(4,50)}=4.001, p=0.0068$ ). Acoustically-exposed fish exhibit highly variable FM 1-43FX loading. $\boldsymbol{E}$, Hair cell survival is reduced $72 \mathrm{~h}$ after acoustic stimulation (one-way ANOVA; post-exposure time: $\left.F_{(4,43)}=17.19, p<0.0001\right)$. Hair cells were labeled with anti-parvalbumin and quantified in fixed animals. Asterisks indicate significant difference from unexposed control $(* * * * p<0.001) . N=8-12$ animals per treatment and values represent mean \pm SD.

\section{Discussion}

We have designed an acoustic trauma device capable of damaging the larval zebrafish lateral line. This device uses ultrasonic transducers to generate a broadband stimulus within the exposure tank, with the greatest energy in the low-frequency range, where the larval lateral line is most sensitive (Van Trump and McHenry, 2008). Both sound pressure and particle motion (acceleration; 

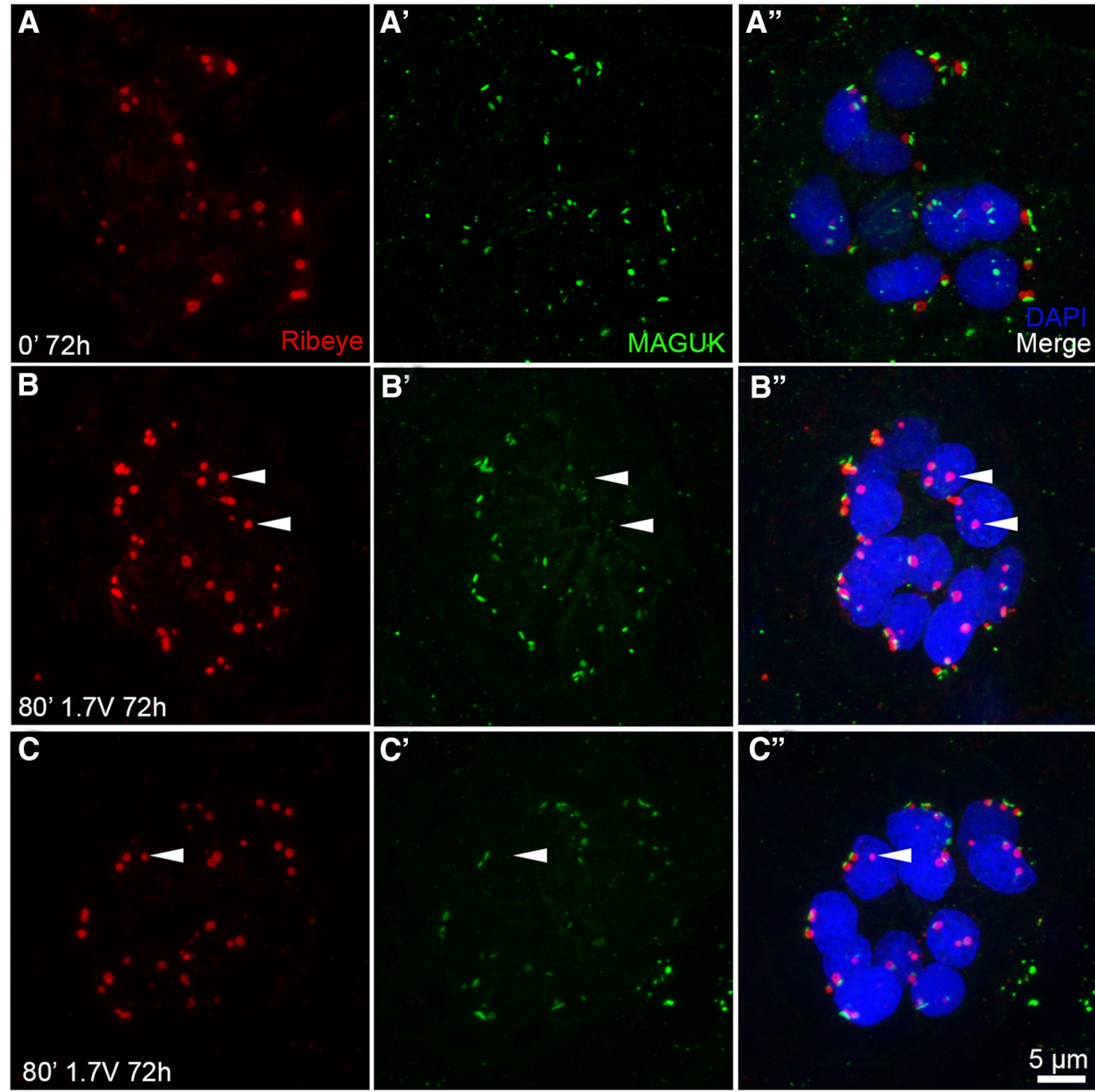

D

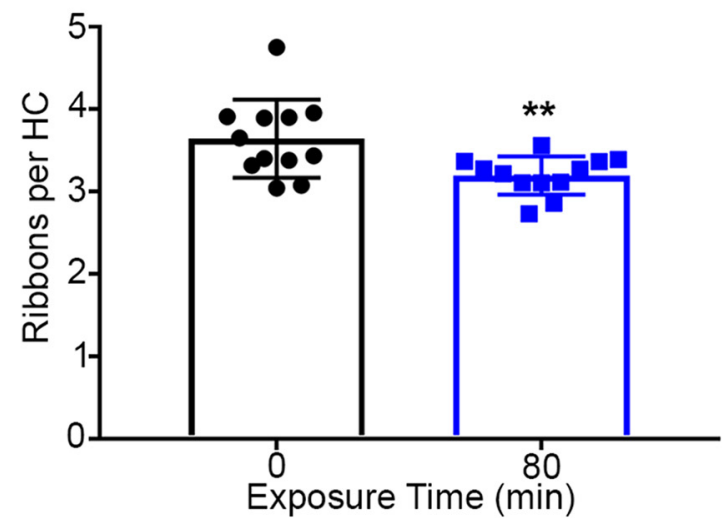

E

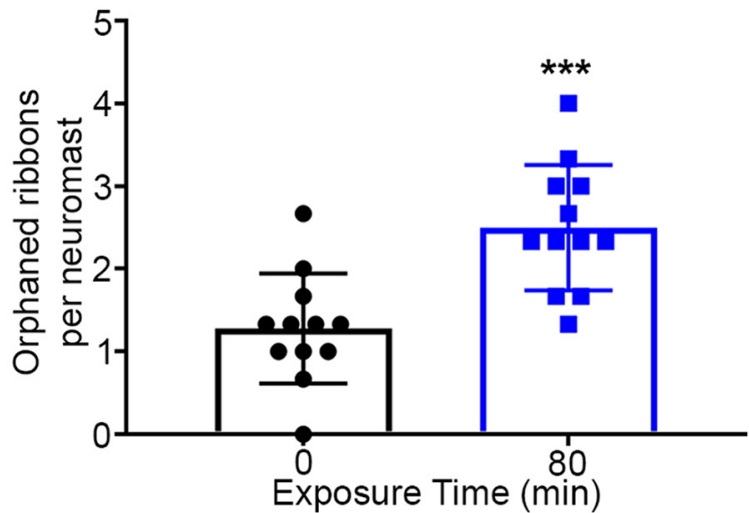

Figure 6. A total of 80 min of acoustic stimulation reduces ribeye puncta and increases the frequency of orphaned ribeye puncta. $A-A^{\prime \prime}$, In unexposed neuromasts, the presynaptic marker ribeye b (red) colocalizes with the postsynaptic marker MAGUK (green). B-C', $72 \mathrm{~h}$ after acoustic stimulation, many orphaned ribeye b puncta are present (white arrows). Hair cells are labeled with DAPI (blue). $\boldsymbol{D}$, Acoustic stimulation significantly reduces the number of synaptic ribbons per hair cell when assessed $72 \mathrm{~h}$ after acoustic stimulation ( $t$ test; $p=0.0079$ ). $\boldsymbol{E}$. Acoustic stimulation increased the number of synaptic ribbons lacking a neighboring MAGUK puncta (orphaned ribbons; $t$ test; $p=0.0004)$. Asterisks indicate significant different from unexposed control $(* * p<0.01, * * * p<$ 0.005). $N=12$ animals per treatment (three neuromasts per animal), values represent mean $\pm \mathrm{SD}$. 


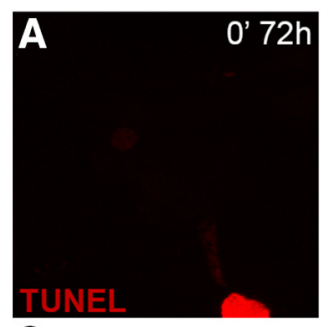

C

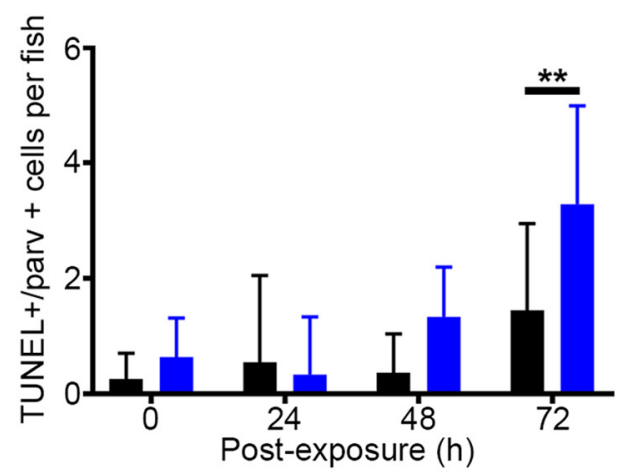

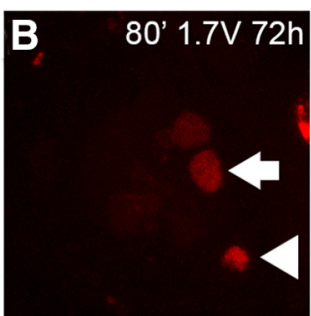

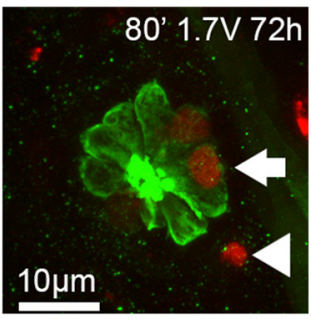

D

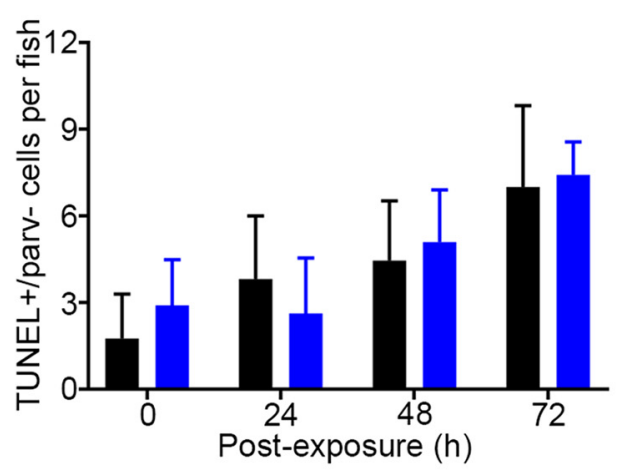

$\square 0^{\prime} \quad \square 80^{\prime} 1.7 \mathrm{~V}$

Figure 7. The number of TUNEL + hair cells increases $72 \mathrm{~h}$ after exposure to acoustic stimulation. $\boldsymbol{A}$, Representative images from unexposed control fish labeled with anti-parvalbumin and processed with the apoptotic maker TUNEL show no TUNEL + cells within the neuromast. $\boldsymbol{B}, 72 \mathrm{~h}$ after noise exposure, TUNEL+ hair cells are present within the IO1 neuromast (arrow). $\boldsymbol{C}$, TUNEL + hair cells are significantly increased over unexposed controls $72 \mathrm{~h}$ post-exposure recovery in IO1, IO2, and IO3 neuromasts (two-way ANOVA; post-exposure time: $F_{(3,71)}=12.09, p<0.0001$; acoustic stimulation: $F_{(1,71)}=9.081, p=0.0036$; interaction: $F_{(3,71)}=2.872, p=$ 0.0423). $\boldsymbol{D}$, TUNEL+ parv- cells (non-hair cells, arrowhead) in unexposed and acoustic stimulation exposed fish are not significantly different over $72 \mathrm{~h}$ of recovery, suggesting that acoustic stimulation specifically damages hair cells (two-way ANOVA; post-exposure time: $F_{(3,72)}=21.91, p<0.0001$; acoustic stimulation: $F_{(1,72)}=0.3405, p=0.5613$; interaction: $\left.F_{(3,72)}=1.345, p=0.2666\right)$. Asterisks indicate significant difference from unexposed control $(* * p<0.01) . N=7-12$ fish per treatment (three neuromasts per fish) and values represent mean $\pm \mathrm{SD}$.

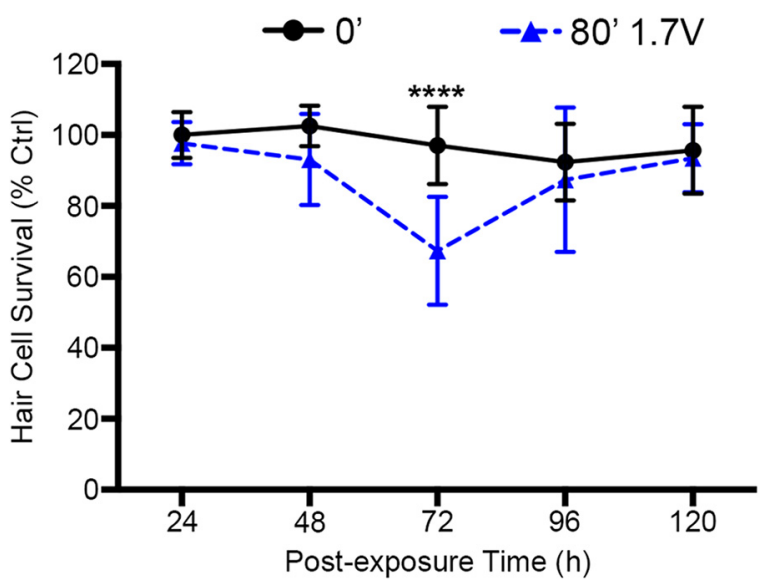

Figure 8. Acoustic stimulation-exposed fish exhibit complete hair cell regeneration. Eighty minutes of $1.7-\mathrm{V}$ acoustic stimulation produces a reduction in DASPEl labeling by $72 \mathrm{~h}$ that is completely reversed by $96 \mathrm{~h}$ post-exposure (two-way ANOVA; post-exposure time: $\left.F_{(4,99)}=7.68, p<0.0001\right)$. Asterisks indicate significant difference from age-matched unexposed control (****p<0.001). $N=10-12$ animals per treatment, values represent mean $\pm \mathrm{SD}$.

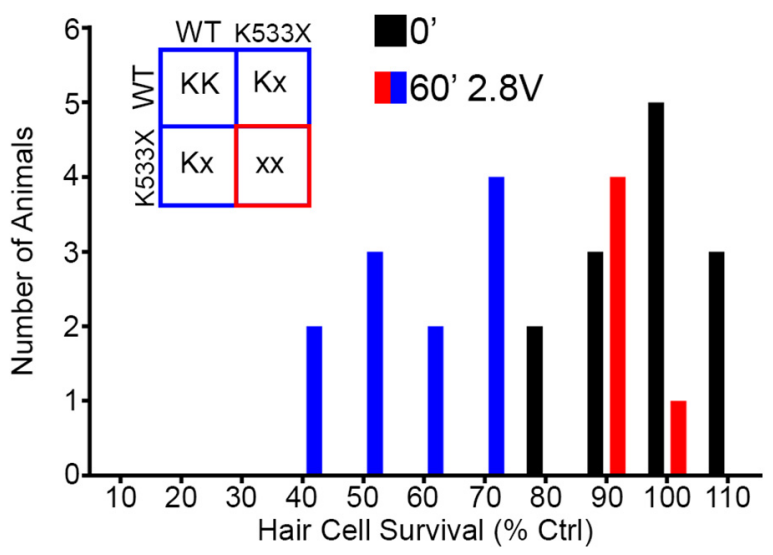

Figure 9. Hair cells in the defective mechanotransduction mutant mariner line are resistant to acoustic stimulation damage. Unexposed F1 progeny from mariner heterozygotes exhibit DASPEI scores centered on $100 \%$. Exposed F1 fish are distributed in two distinct groups that are similar to the predicted Mendelian distribution (inset), where roughly $25 \%$ of fish do not exhibit hair cell damage. $N=13-16$ animals per treatment, data presented as absolute values. 

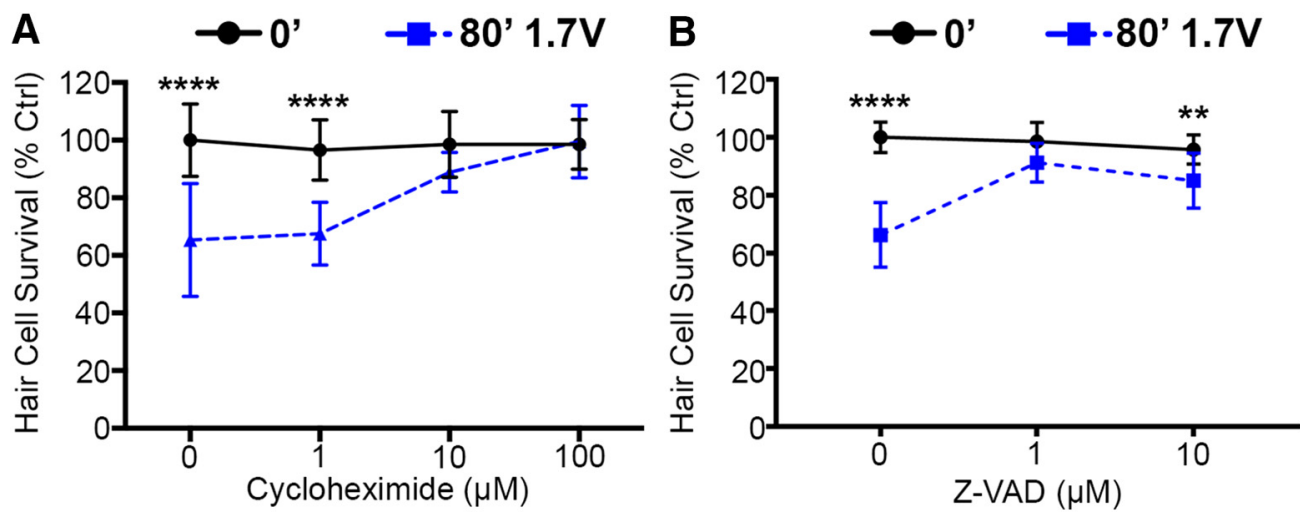

Figure 10. Acoustic stimulation-induced hair cell damage is inhibited by protein synthesis and caspase inhibition. $\boldsymbol{A}$, A 4-h pulse with the protein synthesis inhibitor cycloheximide immediately after acoustic stimulation reduces hair cell damage when assessed $72 \mathrm{~h}$ after acoustic stimulation (two-way ANOVA; cycloheximide: $F_{(3,83)}=10.58, p<0.0001$ ). $\boldsymbol{B}, 72$-h treatment with the pan-caspase inhibitor Z-VAD starting immediately after acoustic stimulation exposure robustly protects hair cells from damage (two-way ANOVA; Z-VAD: $\left.F_{(2,64)}=13.9, p<0.0001\right)$. Asterisks indicate significant difference from unexposed ( 0 ', $0 \mu \mathrm{M}$ cycloheximide/Z-VAD) controls $(* * p<0.01, * * * * p<0.001) . N=11-12$ animals per treatment, values represent mean $\pm \mathrm{SD}$.

Fig. 1D) increase with increasing voltage. The device likely causes damage by cavitation; the generation of microbubbles in the fluid medium, which implode, causing localized particle displacement and the generation of pressure waves. As the larval lateral line is a hydrodynamic system, particle displacement is the likely source of the damage, rather than sound pressure (Chagnaud and Coombs, 2014). In the discussion below, however, we describe the stimulus in terms of sound pressure to facilitate comparison to mammalian studies.
We show that acoustic stimulation specifically damages lateral line hair cells in an exposure time-, post-exposure time-, and intensity-dependent manner. Previous work has reported that saccular hair cells from adult fish are damaged by acoustic trauma (Schuck and Smith, 2009), but our study provides the first evidence of acoustic damage in the lateral line and larval saccule using a single exposure method. Our study characterizes the time course of damage and regeneration following acoustic stimulation, demonstrating that maximum hair cell loss occurs $72 \mathrm{~h}$ post-exposure, and that
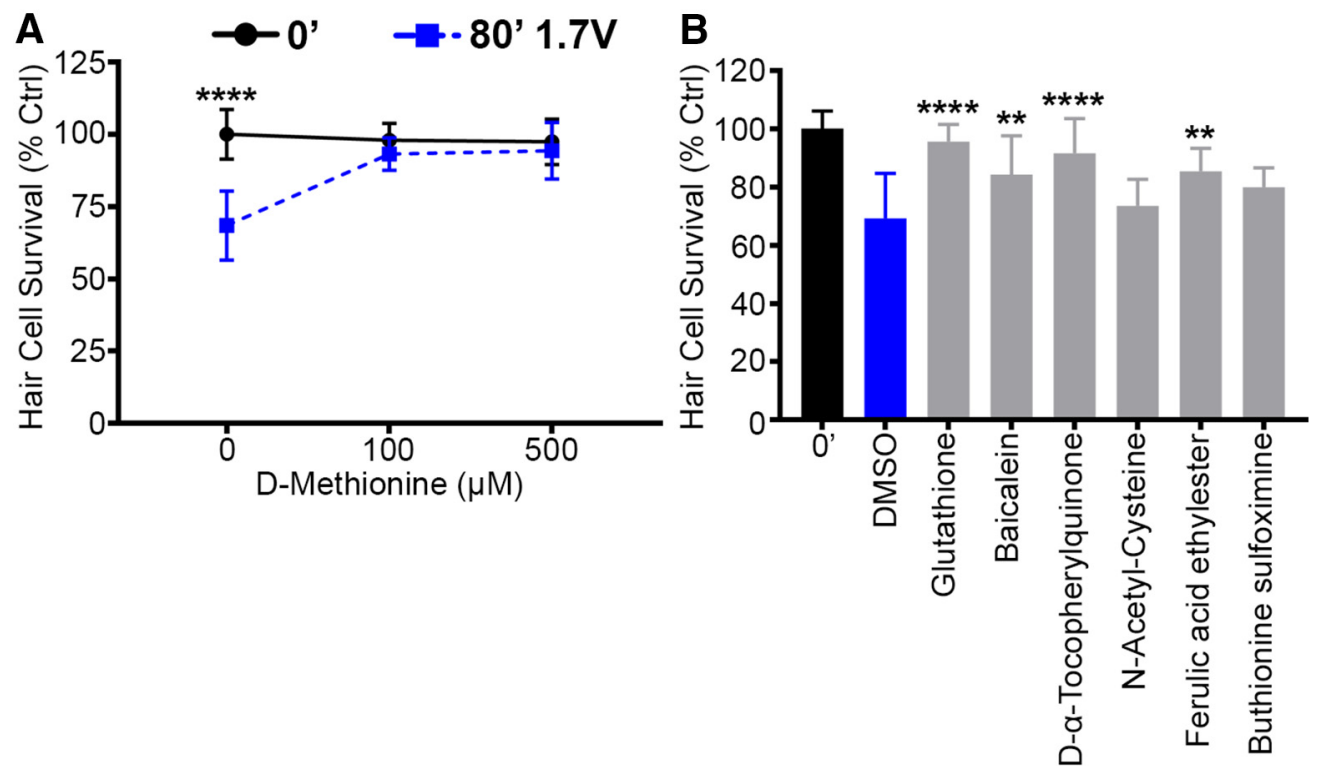

$1 . \overline{7 V} 120$ ' $72 \mathrm{~h}$ post-exposure

Figure 11. Treatment with antioxidants protects lateral line hair cells from acoustic stimulation. $\boldsymbol{A}, 72-\mathrm{h}$ treatment with $\mathrm{D}$-methionine, an antioxidant that prevents NIHL in mammals, robustly protects lateral line hair cells from acoustic stimulation (two-way ANOVA; D-methionine: $\left.F_{(2,69)}=14.92, p<0.0001\right)$. $\boldsymbol{B}$, A mini-screen of five antioxidants and the glutathione inhibitor buthionine sulfoximine (negative control) reveals novel hair cell protectants that have hair cell survival scores higher than vehicle (DMSO) control (one-way ANOVA; antioxidant: $\left.F_{(7,82)}=12.28, p<0.0001\right)$. Asterisks indicate significant difference from unexposed, age-matched controls $(\boldsymbol{A})$ and DMSO-only noise exposed controls $(\boldsymbol{B} ; * * p<0.01$, ****p $<0.001) . N=11-13$ fish per treatment, values represent mean \pm SD. 
significant regeneration occurs by $96 \mathrm{~h}$ post-exposure. We also show that acoustic stimulation results in a reduction of ribeye $b$ puncta and an increase in orphaned synaptic ribbons. Using the mariner mechanotransduction mutants we show that acoustic trauma relies on an intact mechanotransduction apparatus. Acoustic stimulation results in increased TUNEL + hair cells, whereas other non-sensory cell types within the neuromast are unaffected, demonstrating that acoustic stimulation damage is specific to hair cells, rather than causing generalized cellular damage. Collectively, these data demonstrate that acoustic stimulation induces damage to the larval lateral line and recapitulates many of the key features of acoustic trauma in the mammalian cochlea.

Acoustic trauma studies in rodents have examined a range of exposure parameters and post-exposure assessment time points that vary based on the degree of desired damage and species (e.g., chinchilla vs mouse). Many mammalian NIHL studies use 1-2 h of continuous noise at 100- to 120-dB SPL (Ou et al., 2000; Hu et al., 2002; Wang et al., 2002). In mice, 100 dB acoustic trauma (1-2 h of exposure time) results in modest hair cell loss [30\% inner hair cell (IHC) loss, 50\% outer hair cell $(\mathrm{OHC})$ loss], whereas $110 \mathrm{~dB}$ (4-8 h of exposure time) resulted in $46 \%$ IHC loss and 96\% OHC loss (Ou et al., 2000). Chinchillas exposed to 110-dB SPL acoustic trauma for 1 $\mathrm{h}$ exhibit as much as $80 \% \mathrm{OHC}$ loss in the basal region of the cochlea (Hu et al., 2002). In mammals, acoustic trauma results in progressive hair cell loss after cessation of noise, with maximum damage occurring two to four weeks post-exposure (Henderson et al., 1994; Wang et al., 2002). Here, we found that maximum hair cell damage occurred with exposure times of 80-120 min, similar to mammalian NIHL studies. In the lateral line, we observed maximum damage at post-exposure times of 48-72 h, similar to the onset of early stage acoustic trauma in mammals (Wang et al., 2002). However, zebrafish rapidly regenerate damaged hair cells, which may mask assessment of ongoing damage past $72 \mathrm{~h}$ postexposure (Williams and Holder, 2000; Harris et al., 2003).

We also found that lateral line hair cells were damaged by similar sound pressures as mammalian hair cells. Using a hydrophone, we measured sound pressures of 188 and $186 \mathrm{~dB}$ (re:1 $\mu \mathrm{Pa}$ ) for input voltages of 1.2 and 1.7, respectively. It is important to note that our reported values describe sound pressure underwater (dB re:1 $\mu \mathrm{Pa}$ ). When converted to values in air (dB re:20 $\mu \mathrm{Pa}$ ), our recorded values correspond to 126.5- and 128.5-dB SPL, similar to acoustic trauma intensities used to induce hair cell damage and permanent threshold shifts in rodent models (Wang et al., 2002; Hirose and Liberman, 2003). These intensities can damage human hearing in as little as $15 \mathrm{~min}$, and we observed a $12 \%$ hair cell reduction after just 20 min of the 126.5-dB SPL equivalent (Daniel, 2007). However, it is important to note that mammalian auditory sensitivity is greater than that of zebrafish, particularly larval zebrafish, who lack a Weberian apparatus that functions to increase hearing sensitivity (Higgs et al., 2001). While these differences make it difficult to directly cross compare thresholds for hair cell loss or synaptopathy, we are still confident that our model mimics such components of acoustic trauma and thus allows for the translational study of these phenomena. Collectively, these studies suggest that hair cell sensitivity to acoustic trauma may be conserved across vertebrates.

Adult zebrafish exposed to a $100-\mathrm{Hz}$ pure tone at 179 $\mathrm{dB}(\mathrm{re}: 1 \mu \mathrm{Pa})$ for $36 \mathrm{~h}$ exhibit up to $43 \%$ hair cell loss in the caudal saccule (Schuck and Smith, 2009). We report less saccular hair cell damage (14\%) after just $120 \mathrm{~min}$ at 186 $\mathrm{dB}$ (re: $1 \mu \mathrm{Pa}$ ) broadband exposure. The differences in the degree of hair cell damage are likely due to differences in exposure time, and to the absence of Weberian ossicles in larval fish. Weberian ossicles couple the swim bladder to the ear and first appear around $50 \mathrm{dpf}$ (Grande and Young, 2004). The presence of Weberian ossicles coincides with broadening of the detectable frequency range and lack of this coupling diminishes the fish's sensitivity to acoustic stimulation (Higgs et al., 2003). The current study finds that, even in the absence of Weberian ossicles, saccular hair cells are damaged by acoustic trauma. The damage observed in larval fish coupled with the ability to image saccular and lateral line hair cells in intact, live preparations makes the larval zebrafish model of acoustic trauma a compelling model for future mechanistic noise exposure studies.

In rodent models, hair cell loss and damage increase as exposure intensity increases (Hu et al., 2000; Wang et al., 2002). We also found intensity-dependent hair cell loss but with an inflection point at $80 \mathrm{~min}$ of exposure. We hypothesize that, for exposure times longer than $80 \mathrm{~min}$, the onset of hair cell loss occurs rapidly and initiates regeneration while cell death is still occurring, thus masking the maximal effect. To test this hypothesis, future studies can use fate-mapping strategies in the neuromast to differentiate hair cells that were present before acoustic stimulation from newly regenerated hair cells (Suli et al., 2014; Cruz et al., 2015).

Cleaved caspases are present in cochlear cells after acoustic trauma and intracochlear perfusion of the caspase inhibitor Z-VAD reduces hair cell loss in guinea pigs following blast noise (Hu et al., 2002; Nicotera et al., 2003; Abaamrane et al., 2011). We found that Z-VAD completely prevented acoustic trauma in the lateral line. Similar degrees of protection were reported in some mammalian studies (Abaamrane et al., 2011), while other studies find that Z-VAD treatment provides only partial attenuation of acoustic trauma in rodents (Zheng et al., 2014). While the magnitude of protection likely depends on the precise acoustic stimulus employed and the method of Z-VAD delivery, the collective data suggest that reliance on caspase cleavage is conserved between rodent and zebrafish models of acoustic trauma. Differential gene expression patterns have also been identified in noise-exposed cochlea (Cho et al., 2004; Kirkegaard et al., 2006; Yang et al., 2016). The importance of protein synthesis in acoustic trauma is difficult to test in rodents due to the high systemic toxicity of protein synthesis inhibitors (Hoffmann et al., 2010). Zebrafish offer the advantage of treatment via bath-applied inhibitors, which can easily be pulsed to prevent chronic toxicity. We found 
that treatment with cycloheximide for $4 \mathrm{~h}$ after acoustic stimulation prevented hair cell loss when assessed $72 \mathrm{~h}$ later, suggesting that acoustic trauma-induced hair cell damage relies on protein synthesis. These studies demonstrate the ability of the lateral line to elucidate mechanisms of acoustic trauma.

Acoustic trauma results in ROS overproduction in the cochlea that persists for up to $10 \mathrm{~d}$ (Yamane et al., 1995; Vlajkovic et al., 2010). Many antioxidants have been reported to reduce NIHL in rodent models (Ohlemiller, 2008). For example, the antioxidant D-methionine protects cochlear hair cells in rodents from acoustic trauma (Cheng et al., 2008; Samson et al., 2008). However, a clinical trial using $\mathrm{N}$-acetylcysteine to prevent $\mathrm{NIHL}$ showed some promise but failed to meet clinical endpoints (Kopke et al., 2015). In the present study, we report that D-methionine completely protects lateral line hair cells from the damaging effects of acoustic stimulation. Such robust protection is not regularly observed in rodent studies, likely because those studies often use systemic injection of antioxidants, rather than the direct immersion method employed here (Samson et al., 2008; Clifford et al., 2011). However, antioxidant protection from acoustic trauma is clearly conserved between fish and mammals. Zebrafish are a productive tool to identify new compounds that prevent drug-induced hair cell death, with some compounds demonstrating protection in mammalian models of ototoxicity (Owens et al., 2008; Vlasits et al., 2012; Chowdhury et al., 2018). Building on the success of these otoprotective screens, we performed a phenotypic hair cell protection screen of a redox library and identified three novel protective antioxidants and confirmed the protective potential of glutathione. Future work will expand on this screen to identify additional novel compounds that prevent acoustic trauma-induced hair cell death with the goal of developing preventative therapies.

The discovery of cochlear synaptopathy transformed our understanding of sound levels that were previously thought to be innocuous (Kujawa and Liberman, 2009). The phenomenon of synaptopathy appears to be well conserved across species. Synaptopathy has been observed in rodents and nonhuman primates and its existence in humans is supported by some physiologic evidence (Liberman et al., 2016; Valero et al., 2017). The characteristic phenotype of synaptopathy includes a decrease in ribbon synapse density and an increase in isolated ribbon synapses that lack a paired postsynaptic density (Sergeyenko et al., 2013). Zebrafish studies using direct application of AMPA suggest that this damage is mediated by calcium permeable AMPARs, however, mechanistic studies with physiologically relevant stimuli are needed (Sebe et al., 2017). In the present study we demonstrate that acoustic stimulation likely produced by cavitation results in decreased ribeye $b$ puncta and increased orphaned ribbons, indicative of synaptopathy. Our data are consistent with synaptic changes in noisedamaged cochlear hair cells and allow for future mechanistic dissection of synaptopathy using physiologically relevant stimuli.
While the zebrafish lateral line cannot model all of the features of cochlear injury (e.g., stria swelling), we demonstrate that use of this model allows us to isolate hair cell-specific responses to acoustic trauma using an in vivo preparation. In summary, our study demonstrates that our novel cavitation system represents an accessible in vivo model for accelerating our understanding of acoustic trauma and developing protective therapies.

\section{References}

Abaamrane L, Raffin F, Schmerber S, Sendowski I (2011) Intracochlear perfusion of leupeptin and Z-VAD-FMK: influence of antiapoptotic agents on gunshot-induced hearing loss. Eur Arch Otorhinolaryngol 268:987-993. CrossRef Medline

Bielefeld EC, Kopke RD, Jackson RL, Coleman JK, Liu J, Henderson D (2007) Noise protection with $\mathrm{N}$-acetyl-I-cysteine (NAC) using a variety of noise exposures, NAC doses, and routes of administration. Acta Oto-Laryngol 127:914-919. CrossRef Medline

Bureau of Labor Statistics (2006) Workplace injuries and illnesses in 2006. United States Department of Labor

Chagnaud BP, Coombs S (2014) Information encoding and processing by the peripheral lateral line system. In: The lateral line system (Coombs S, Bleckmann H, Fay RR, Popper AN, eds), pp 151-194. New York, NY: Springer.

Cheng PW, Liu SH, Young YH, Hsu CJ, Lin-Shiau SY (2008) Protection from noise-induced temporary threshold shift by D-methionine is associated with preservation of ATPase activities. Ear Hear 29:65-75. CrossRef Medline

Cho Y, Gong TW, Kanicki A, Altschuler RA, Lomax MI (2004) Noise overstimulation induces immediate early genes in the rat cochlea. Brain Res Mol Brain Res 130:134-148. CrossRef Medline

Chowdhury S, Owens KN, Herr RJ, Jiang Q, Chen X, Johnson G, Groppi VE, Raible DW, Rubel EW, Simon JA (2018) Phenotypic optimization of urea-thiophene carboxamides to yield potent, well tolerated and orally active protective agents against aminoglycoside-induced hearing loss. J Med Chem 61:84-97. CrossRef Medline

Clifford RE, Coleman JKM, Balough BJ (2011) Low-dose $\mathrm{D}$-methionine and $\mathrm{N}$-acetyl-cysteine for protection from permanent noise-induced hearing loss in chinchillas. Otolaryngol Head Neck Surg 145:999-1106. CrossRef

Coffin AB, Reinhart KE, Owens KN, Raible DW, Rubel EW (2009) Extracellular divalent cations modulate aminoglycoside-induced hair cell death in the zebrafish lateral line. Hear Res 253:42-51. CrossRef Medline

Coffin AB, Rubel EW, Raible DW (2013) Bax, Bcl2, and p53 differentially regulate neomycin- and gentamicin-induced hair cell death in the zebrafish lateral line. J Assoc Res Otolaryngol 14:645-659. CrossRef

Cruz IA, Kappedal R, Mackenzie SM, Hailey DW, Hoffman TL, Schilling TF, Raible DW (2015) Robust regeneration of adult zebrafish lateral line hair cells reflects continued precursor pool maintenance. Dev Biol 402:229-238. CrossRef Medline

Dijkgraaf S (1963) The functioning and significance of the lateral-line organs. Biol Rev 38:51-105. Medline

Daniel E (2007) Noise and hearing loss: a review. J Sch Health 77:225-231. CrossRef Medline

Ernest S, Rauch GJ, Haffter P, Geisler R, Petit C, Nicolson T (2000) Mariner is defective in myosin VIIA: a zebrafish model for human hereditary deafness. Hum Mol Genet 9:2189-2196. Medline

Esterberg R, Coffin AB, Ou H, Simon JA, Raible DW, Rubel EW (2013) Fish in a dish: drug discovery for hearing habilitation. Drug Discov Today: Dis Models 10:e23-e29. CrossRef

Esterberg R, Hailey DW, Rubel EW, Raible DW (2014) ERmitochondrial calcium flow underlies vulnerability of mechanosensory hair cells to damage. J Neurosci 34:9703-9719. CrossRef Medline 
Fernandez KA, Jeffers PWC, Lall K, Liberman MC, Kujawa SG (2015) Aging after noise exposure: acceleration of cochlear synaptopathy in "recovered" ears. J Neurosci 35:7509-7520. CrossRef

Fetoni AR, De Bartolo P, Eramo SL, Rolesi R, Paciello F, Bergamini C, Fato R, Paludetti G, Petrosini L, Troiani D (2013) Noise-induced hearing loss $(\mathrm{NIHL})$ as a target of oxidative stress-mediated damage: cochlear and cortical responses after an increase in antioxidant defense. J Neurosci 33:4011-4023. CrossRef Medline

Grande T, Young B (2004) The ontogeny and homology of the Weberian apparatus in the zebrafish Danio rerio (Ostariophysi: Cypriniformes). Zool J Lin Soc 140:241-254. CrossRef

Harris JA, Cheng AG, Cunningham LL, MacDonald G, Raible DW, Rubel EW (2003) Neomycin-induced hair cell death and rapid regeneration in the lateral line of zebrafish (Danio rerio). J Assoc Res Otolaryngol 4:219-234. CrossRef Medline

Henderson D, Spongr V, Subramaniam M, Campo P (1994) Anatomical effects of impact noise. Hear Res 76:101-117. Medline

Henderson D, Bielefeld EC, Harris KC, Hu BH (2006) The role of oxidative stress in noise-induced hearing loss. Ear Hear 27:1-19. CrossRef Medline

Higgs DM, Souza MJ, Wilkins HR, Presson JC, Popper AN (2001) Age- and size-related changes in the inner ear and hearing ability of the adult zebrafish (Danio rerio). J Assoc Res Otolaryngol 3:174-184. Medline

Higgs DM, Rollo AK, Souza MJ, Popper AN (2003) Development of form and function in peripheral auditory structures of the zebrafish (Danio rerio). J Acoust Soc Am 113:1145-1154. Medline

Hirose K, Liberman MC (2003) Lateral wall histopathology and endocochlear potential in the noise-damaged mouse cochlea. $J$ Assoc Res Otolaryngol 4:339-352. CrossRef Medline

Hoffmann S, Kinsner-Ovaskainen A, Prieto P, Mangelsdorf I, Bieler C, Cole T (2010) Acute oral toxicity: variability, reliability, relevance and interspecies comparison of rodent LD50 data from literature surveyed for the ACuteTox project. Regul Toxicol Pharmacol 58: 395-407. CrossRef Medline

Hu BH, Guo W, Wang PY, Henderson D, Jiang SC (2000) Intense noise-induced apoptosis in hair cells of guinea pig cochleae. Acta Oto-Laryngol 120:19-24. Medline

Hu BH, Henderson D, Nicotera TM (2002) Involvement of apoptosis in progression of cochlear lesion following exposure to intense noise. Hear Res 166:62-71. Medline

Husbands JM, Steinberg SA, Kurian R, Saunders JC (1999) Tip-link integrity on chick tall hair cell stereocilia following intense sound exposure. Hear Res 135:135-145. Medline

Kindt KS, Finch G, Nicolson T (2012) Kinocilia mediate mechanosensitivity in developing zebrafish hair cells. Dev Cell 23:329-341. CrossRef Medline

Kirkegaard M, Murai N, Risling M, Suneson A, Järlebark L, Ulfendahl M (2006) Differential gene expression in the rat cochlea after exposure to impulse noise. Neuroscience 142:425-435. CrossRef Medline

Kopke R, Slade MD, Jackson R, Hammill T, Fausti S, LonsburyMartin B, Sanderson A, Dreisbach L, Rabinowitz P, Torre P 3rd, Balough B (2015) Efficacy and safety of $\mathrm{N}$-acetylcysteine in prevention of noise induced hearing loss: a randomized clinical trial. Hear Res 323:40-50. CrossRef

Kruger M, Boney R, Ordoobadi AJ, Sommers TF, Trapani JG, Coffin AB (2016) Natural bizbenzoquinoline derivatives protect zebrafish lateral line sensory hair cells from aminoglycoside toxicity. Front Cell Neurosci 10:83. CrossRef Medline

Kujawa SG, Liberman MC (2009) Adding insult to injury: cochlear nerve degeneration after "temporary" noise-induced hearing loss. J Neurosci 29:14077-14085. CrossRef Medline

Kurabi A, Keithley EM, Housley GD, Ryan AF, Wong AC (2017) Cellular mechanisms of noise-induced hearing loss. Hear Res 349:129-137. CrossRef Medline

Leighton TG (1994) The acoustic bubble. San Diego, CA: Academic Press.
Le Prell CG, Yamashita D, Minami SB, Yamasoba T, Miller JM (2007) Mechanisms of noise-induced hearing loss indicate multiple methods of prevention. Hear Res 226:22-43. CrossRef Medline

Liberman MC, Epstein MJ, Cleveland SS, Wang H, Maison SF (2016) Toward a differential diagnosis of hidden hearing loss in humans. PLoS One 11:e0162726. CrossRef Medline

Liberman MC, Kujawa SG (2017) Cochlear synaptopathy in acquired sensorineural hearing loss: manifestations and mechanisms. Hear Res 349:138-147. CrossRef Medline

Ma EY, Rubel EW, Raible DW (2008) Notch signaling regulates the extent of hair cell regeneration in the zebrafish lateral line. $J$ Neurosci 28:2261-2273. CrossRef Medline

Mathias JR, Saxena MT, Mumm JS (2012) Advances in zebrafish chemical screening technologies. Future Med Chem 14:18111822. CrossRef Medline

Mick P, Kawachi I, Lin FR (2014) The association between hearing loss and social isolation in older adults. Otolaryngol Head Neck Surg 150:378-384. CrossRef Medline

Minami SB, Yamashita D, Ogawa K, Schacht J, Miller JM (2007) Creatine and tempol attenuate noise-induced hearing loss. Brain Res 1148:83-89. CrossRef Medline

Nicolson T (2017) The genetics of hair-cell function in zebrafish. $J$ Neurogenet 31:102-112. CrossRef Medline

Nicolson T, Rüsch A, Friedrich RW, Granato M, Ruppersberg JP, Nüsslein-Volhard C (1998) Genetic analysis of vertebrate sensory hair cell mechanosensation: the zebrafish circler mutants. Neuron 20:271-283. Medline

Nicotera TM, Hu BH, Henderson D (2003) The caspase pathway in noise-induced apoptosis of the chinchilla cochlea. J Assoc Res Otolaryngol 4:466-477. CrossRef Medline

Ohinata Y, Yamasoba T, Schacht J, Miller JM (2000) Glutathione limits noise-induced hearing loss. Hear Res 146:28-34. Medline

Ohlemiller KK (2008) Recent findings and emerging questions in cochlear noise injury. Hear Res 245:5-17. CrossRef Medline

Ou HC, Bohne BA, Harding GW (2000) Noise damage in the C57BL/ CBA mouse cochlea. Hear Res 145:111-122. Medline

Owens KN, Santos F, Roberts B, Linbo T, Coffin AB, Knisely AJ, Simon JA, Rubel EW, Raible DW (2008) Identification of genetic and chemical modulators of zebrafish mechanosensory hair cell death. PLoS Genet 4:e1000020. CrossRef Medline

Pickles JO, Osborne MP, Comis SD (1987) Vulnerability of tip links between stereocilia to acoustic trauma in the guinea pig. Hear Res 25:173-183. Medline

Popper AN, Fay RR (1973) Sound detection and processing by teleost fishes: a critical review. J Acoust Soc Am 53:1515-1529. Medline

Pourbakht A, Yamasoba T (2003) Ebselen attenuates cochlear damage caused by acoustic trauma. Hear Res 181:100-108. Medline

Raible DW, Kruse GJ (2000) Organization of the lateral line system in embryonic zebrafish. J Comp Neur 421:189-198. Medline

Samson J, Wiktorek-Smagur A, Politanski P, Rajkowska E, Pawlaczyk-Luszczynska M, Dudarewicz A, Sha SH, Schacht J, Sliwinska-Kowalska M (2008) Noise-induced time-dependent changes in oxidative stress in the mouse cochlea and attenuation by D-methionine. Neuroscience 152:146-150. CrossRef Medline

Schuck JB, Smith ME (2009) Cell proliferation follows acousticallyinduced hair cell bundle loss in the zebrafish saccule. Hear Res 253:67-76. CrossRef Medline

Sebe JY, Cho S, Sheets L, Rutherford MA, von Gersdorff H, Raible DW (2017) $\mathrm{Ca}(2+)$-permeable AMPARs mediate glutamatergic transmission and excitotoxic damage at the hair cell ribbon synapse. J Neurosci 37:6162-6175. CrossRef Medline

Sergeyenko Y, Lall K, Liberman MC, Kujawa SG (2013) Age-related cochlear synaptopathy: an early-onset contributor to auditory functional decline. J Neurosci 33:13686-13694. CrossRef

Sergi B, Fetoni AR, Paludetti G, Ferraresi A, Navarra P, Mordente A, Troiani D (2006) Protective properties of idebenone in noiseinduced hearing loss in the guinea pig. Neuroreport 17:857-861. CrossRef Medline 
Sheets L, Trapani JG, Mo W, Obholzer N, Nicolson T (2011) Ribeye is required for presynaptic $\mathrm{Ca}(\mathrm{V}) 1.3 \mathrm{a}$ channel localization and afferent innervation of sensory hair cells. Development 138:13091319. CrossRef Medline

Sly DJ, Campbell L, Uschakov A, Saief ST, Lam M, O'Leary SJ (2016) Applying neurotrophins to the round window rescues auditory function and reduces inner hair cell synaptopathy after noiseinduced hearing loss. Otol Neurotol 37:1223-1230. CrossRef

Suli A, Guler AD, Raible DW, Kimelman D (2014) A targeted gene expression system using the tryptophan repressor in zebrafish shows no silencing in subsequent generations. Development 141: 1167-1174. CrossRef Medline

Suzuki J, Corfas G, Liberman MC (2016) Round-window delivery of neurotrophin 3 regenerates cochlear synapses after acoustic overexposure. Sci Rep 6:24907. CrossRef Medline

Thomas AJ, Hailey DW, Stawicki TM, Wu P, Coffin AB, Rubel EW, Raible DW, Simon JA, Ou HC (2013) Functional mechanotransduction is required for cisplatin-induced hair cell death in the zebrafish lateral line. J Neurosci 33:4405-4414. CrossRef Medline

Uribe PM, Kawas LH, Harding JW, Coffin AB (2015) Hepatocyte growth factor mimetic protects lateral line hair cells from aminoglycoside exposure. Front Cell Neurosci 9:3. CrossRef Medline

Valero MD, Burton JA, Hauser SN, Hackett TA, Ramachandran R, Liberman MC (2017) Noise-induced cochlear synaptopathy in rhesus monkeys (Macaca mulatta). Hear Res 353:213-223. CrossRef Medline

Van Trump WJ, McHenry MJ (2008) The morphology and mechanical sensitivity of lateral line receptors in zebrafish larvae (Danio rerio). J Exp Biol 211:2105-2115. CrossRef Medline

Vasconcelos RO, Sisneros JA, Amorim MC, Fonseca PJ (2011) Auditory saccular sensitivity of the vocal Lusitanian toadfish: low frequency tuning allows acoustic communication throughout the year. J Comp Physiol A Neuroethol Sens Neural Behav Physiol 197:903-913. CrossRef Medline

Vlajkovic SM, Lee KH, Wong AC, Guo CX, Gupta R, Housley GD, Thorne PR (2010) Adenosine amine congener mitigates noiseinduced cochlear injury. Purinergic Signal 6:273-281. CrossRef Medline

Vlasits AL, Simon JA, Raible DW, Rubel EW, Owens KN (2012) Screen of FDA-approved drug library reveals compounds that protect hair cells from aminoglycosides and cisplatin. Hear Res 294:153-165. CrossRef Medline

Wang Q, Steyger PS (2009) Trafficking of systemic fluorescent gentamicin into the cochlea and hair cells. J Assoc Res Otolaryngol 10:205-219. CrossRef Medline

Wang Y, Hirose K, Liberman MC (2002) Dynamics of noise-induced cellular injury and repair in the mouse cochlea. J Assoc Res Otolaryngol 3:248-268. CrossRef Medline

Williams JA, Holder N (2000) Cell turnover in neuromasts of zebrafish larvae. Hear Res 143:171-181. Medline

Wysocki LE, Codarin A, Ladich F, Picciulin M (2009) Sound pressure and particle acceleration audiograms in three marine fish species from the Adriatic Sea. J Acoust Soc Am 126:2100-2107. CrossRef Medline

Yamane H, Nakai Y, Takayama M, Iguchi H, Nakagawa T, Kojima A (1995) Appearance of free radicals in the guinea pig inner ear after noise-induced acoustic trauma. Eur Arch Otorhinolaryngol 252: 504-508. Medline

Yang S, Cai Q, Vethanayagam RR, Wang J, Yang W, Hu BH (2016) Immune defense is the primary function associated with the differentially expressed genes in the cochlea following acoustic trauma. Hear Res 333:283-294. CrossRef Medline

Zheng H-W, Chen J, Sha S-H (2014) Receptor-interacting protein kinases modulate noise-induced sensory hair cell death. Cell Death Dis 5:e1262. CrossRef Medline 